\title{
Antigua and Barbuda: 2006 Article IV Consultation-Staff Report; Staff Statement; Public Information Notice on the Executive Board Discussion; and Statement by the Authorities of Antigua and Barbuda
}

Under Article IV of the IMF's Articles of Agreement, the IMF holds bilateral discussions with members, usually every year. In the context of the 2006 Article IV consultation with Antigua and Barbuda, the following documents have been released and are included in this package:

- the staff report for the 2006 Article IV consultation, prepared by a staff team of the IMF, following discussions that ended on September 12, 2006, with the officials of Antigua and Barbuda on economic developments and policies. Based on information available at the time of these discussions, the staff report was completed on December 5, 2006. The views expressed in the staff report are those of the staff team and do not necessarily reflect the views of the Executive Board of the IMF;

- a staff statement of January 12, 2007 updating information on recent developments;

- a Public Information Notice (PIN) summarizing the views of the Executive Board as expressed during its January 17, 2007 discussion of the staff report that concluded the Article IV consultation; and

- $\quad$ a statement by the authorities of Antigua and Barbuda.

The document listed below has been or will be separately released.

\section{Statistical Appendix}

The policy of publication of staff reports and other documents allows for the deletion of market-sensitive information.

To assist the IMF in evaluating the publication policy, reader comments are invited and may be sent by e-mail to publicationpolicy@imf.org.

Copies of this report are available to the public from

International Monetary Fund • Publication Services

$70019^{\text {th }}$ Street, N.W. • Washington, D.C. 20431

Telephone: (202) 623-7430 • Telefax: (202) 623-7201

E-mail: publications@imf.org • Internet: http://www.imf.org

Price: $\$ 18.00$ a copy

\section{International Monetary Fund Washington, D.C.}





\title{
INTERNATIONAL MONETARY FUND
}

\author{
ANTIGUA AND BARBUDA \\ Staff Report for the 2006 Article IV Consultation \\ Prepared by Staff Representatives for the 2006 Consultation with Antigua and Barbuda \\ Approved by Ranjit Teja and Matthew Fisher
}

December 5, 2006

\begin{abstract}
Developments. Antigua and Barbuda is experiencing its fastest growth in decades, led by private investment and preparations for the 2007 Cricket World Cup. A bold policy effort is underway to tackle long-standing fiscal and debt problems, and raise growth prospects. However, despite important progress, major challenges remain to secure a lasting improvement in public finances.

Focus. Discussions centered on reforms to restore sound public finances and sustain economic growth. This report is complemented by the staff report for the 2006 Eastern Caribbean Currency Union (ECCU) regional discussions that covers common regional issues, including banking supervision.
\end{abstract}

Mission. Discussions were held in St. John's during August 30-September 12 with representatives from the private sector, civil society, and the government, including Prime Minister Spencer and Finance Minister Cort. The mission comprised Ulric Erickson von Allmen (Head, PDR), Rupa Duttagupta, Koffie Nassar (both WHD), and Dmitriy Kovtun (PDR). David O. Robinson (WHD) and Shawn Ladd (OED) participated in the closing discussions.

Last Article IV Consultation (concluded on December 21, 2005; IMF Country Report No. 06/145). Directors commended the efforts to address the country's economic problems, and urged the authorities to take advantage of strong near-term growth prospects to implement further fiscal, labor market, financial sector and other structural reforms to consolidate fiscal balances and raise the growth potential.

Statistics and Fund Relations. The lack of comprehensive data is an issue for surveillance. 


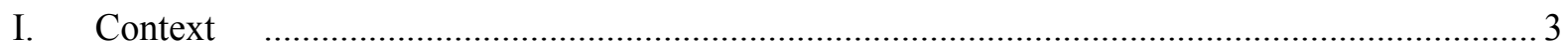

II. Economic Backdrop and Outlook .................................................................................. 3

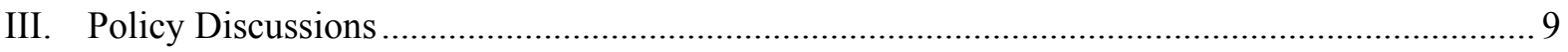

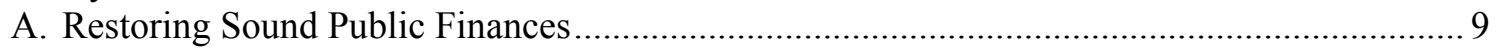

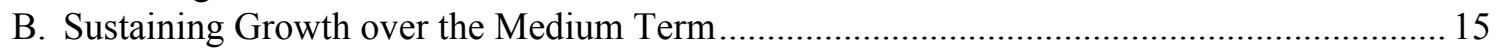

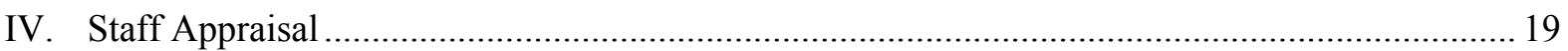

Text Boxes

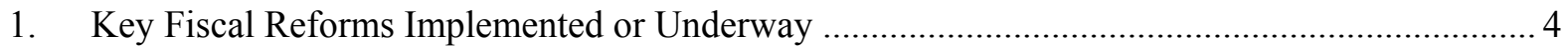

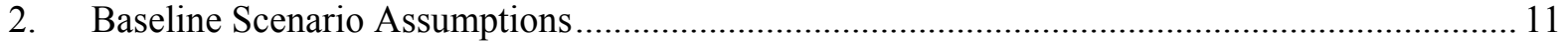

Figures

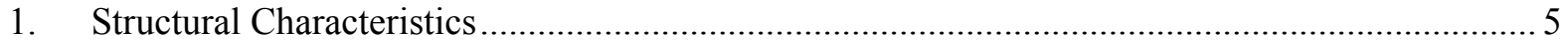

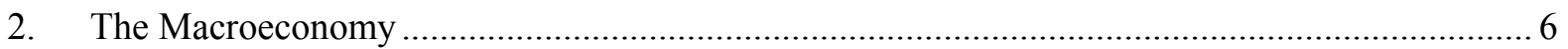

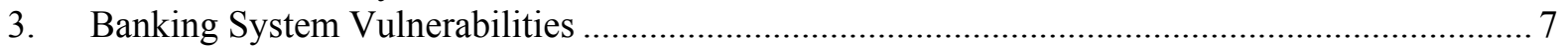

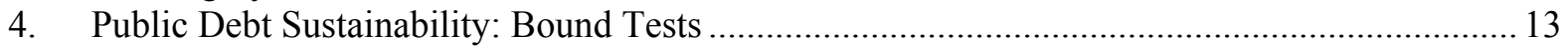

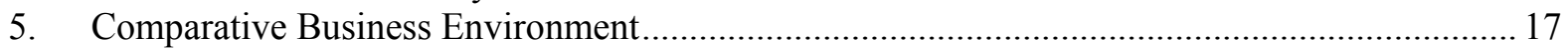

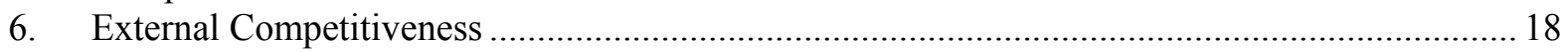

7. External Debt Sustainability: Bound Tests......................................................................... 29

Tables

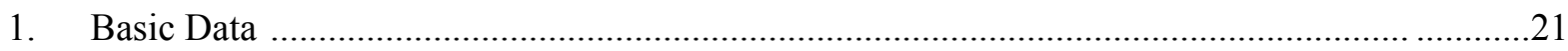

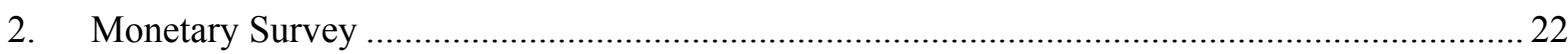

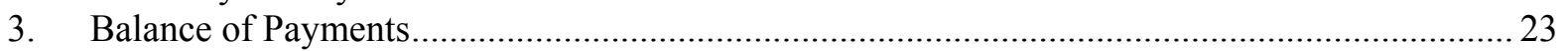

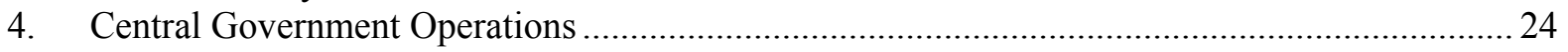

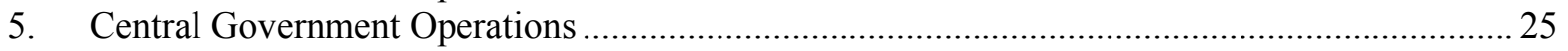

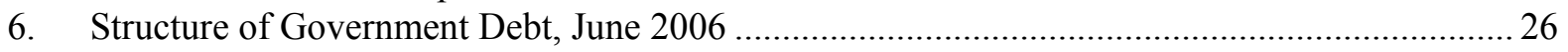

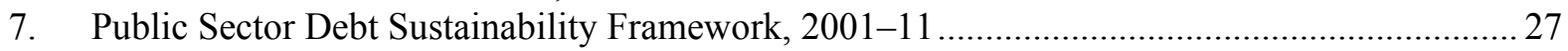

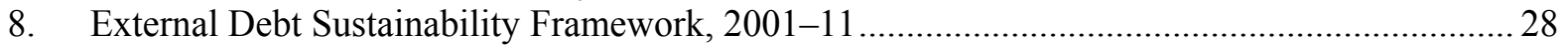

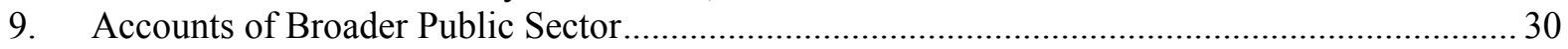

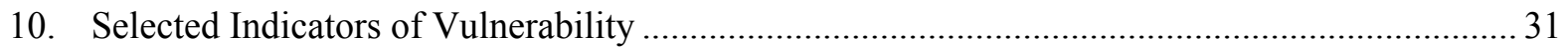

Annex

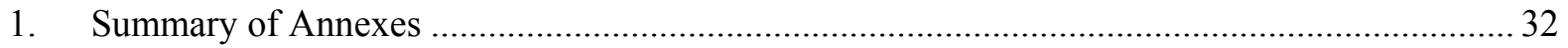

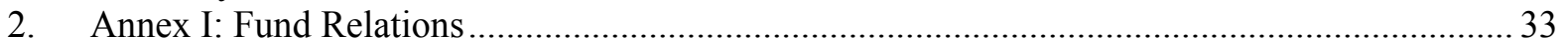

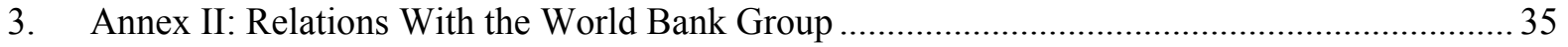

4. Annex III: Relations With the Caribbean Development Bank .................................................. 36

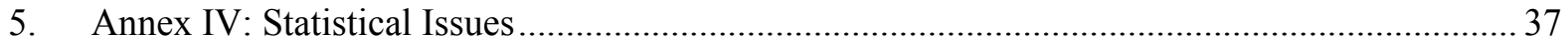

6. Annex V: Table of Common Indicators Required for Surveillance …….................................. 39 


\section{Context}

1. The coming year could be a watershed for Antigua and Barbuda, with the authorities coming to grips with long-standing fiscal and debt problems. The government that took office in 2004 has adopted an ambitious policy agenda to tackle decades of weak public finances - epitomized by persistent fiscal deficits, a triple-digit debt-GDP ratio, endemic arrears, and a large civil service - and raise growth prospects. In the context of strong economic growth, led by private investment and preparations for the 2007 Cricket World Cup, the authorities have launched fiscal reforms (Box 1), measures to improve the investment climate, and are developing a strategy to regularize arrears. These efforts have been underpinned by outreach to build public support.

2. At the same time, sound public finances is still a work in progress. While the fiscal position has improved, deficits remain large, government debt is high, and arrears continue to be incurred. Even with a sizeable fiscal adjustment, large financing requirements will remain. The reform agenda for the coming year is important and includes two crucial fiscal measures: the introduction of the value-added tax (VAT) and completion of the civil service separation program. Ahead of the 2009 elections, there are risks of policy slippages.

\section{ECONOMIC BACKDROP AND OUTLOOK}

3. The economy is enjoying its third year of vigorous growth and low inflation (Figures 1-2; Tables 1-3). Performance has been helped by a generally supportive international environment, improved government policies, and absence of natural disasters. Available indicators suggest the following:

- $\quad$ Output. Staff projects real GDP growth at 8 percent in 2006 - among the highest in the region-led by hotel and housing investments and World Cup-related activities. For 2007-08, growth in the tourism sector, which has operated at capacity, is expected to benefit from the expanded hotel capacity and planned improvements in infrastructure (airport and roads). Nonetheless, GDP growth will likely cool in 2007-08 as the construction boom winds down.

- Labor markets. Strong demand, skills-mismatches, and a stagnant domestic work force are causing labor shortages in key sectors, for example, hotel and construction. In response, the authorities have increased the number of permits issued to foreign workers. Still, unemployment remains high (reportedly 9 percent). ${ }^{1}$

\footnotetext{
${ }^{1}$ The reported figure is not recognized by the government, however.
} 
- Inflation. Despite strong demand and higher domestic petroleum prices, inflation has remained low in the context of the ECCU and its quasi-currency board arrangement. The VAT introduction will cause an up-tick in prices in 2007 (about 11/2 percent).

- Balance of payments. The current account deficit is projected to widen to 20 percent of GDP in 2006, reflecting FDI-financed investment.

Antigua and Barbuda: Private Credit Growth (Annual percentage change)

- $\quad$ Financial sector (Figure 3). Rapid credit growth poses a risk for bank health given the high share of nonperforming loans in local banks (19 percent of total loans). To address financial sector vulnerabilities, the uniform Banking Act, which provides more regulatory teeth to the Eastern Caribbean Central Bank (ECCB), was approved in January 2006, and banks are now also

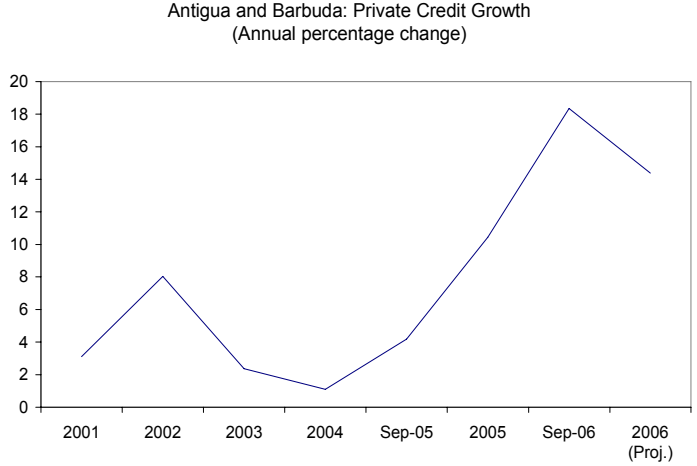
required to provision 10 percent of public sector arrears. Nonbanking institutions, insurance companies and credit unions, are increasingly competing with banks for deposits and credit. Draft legislation for supervision of these institutions is with Parliament. To strengthen the Anti-Money Laundering effort, the authorities have prepared, with technical assistance, a "Best-Practices Handbook" for financial investigations.

\section{Box 1. Antigua and Barbuda: Key Fiscal Reforms Implemented or Underway}

- Personal income tax—reintroduced in April 2005; to yield 1.7 percent of GDP in 2006.

- Property tax - the tax base was broadened in February 2006, and a move to a market value-based system is planned in January 2007.

- VAT - scheduled to be introduced in January 2007 at a 15 percent rate, with a transitional rate of 10.5 percent for hotels. The VAT, expected to yield 3 percent of GDP (in additional revenue) over the medium term, replaces the consumption duty, telecommunication tax, and various hotel taxes.

- Excise taxes - to be introduced with the VAT, but law has yet to be passed by Parliament.

- Voluntary civil service separation program-1,078 civil servants (about 10 percent of the total) applied for separation and early retirement. The pace of the program slowed in 2006 and it is now expected to be implemented over 2006-07.

- Social security reform — the authorities discussed the need for reform at a public symposium in July 2006, and intend to publish a white paper on reform options soon.

- Public expenditure reform - the revised Finance, Administration, and Audit, and Procurement Acts will provide greater oversight of the broader public sector. The legislation is with Parliament. The Free Balance cash management system has been implemented in the Ministry of Finance and is expected to cover all ministries by end-2006.

- Debt strategy - the government has publicly announced its intentions to regularize arrears and bring debt to a more manageable level, and is developing a strategy with its financial advisors. 
Figure 1. Antigua and Barbuda: Structural Characteristics

Antigua and Barbuda is a small open economy with high living standards.

It is a small island country...

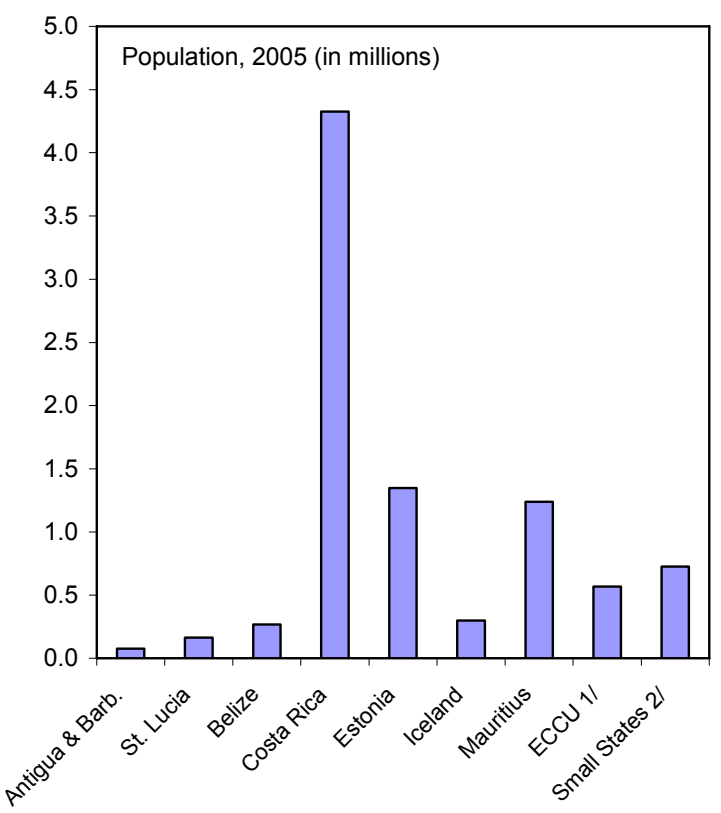

Living standards are high by regional standards...

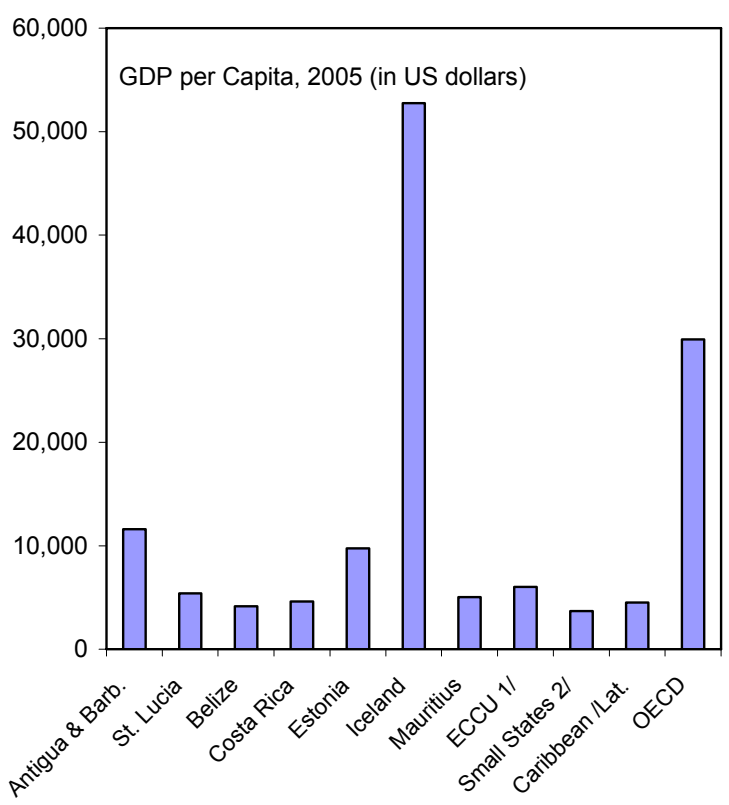

...open in international trade and dependent on tourism.

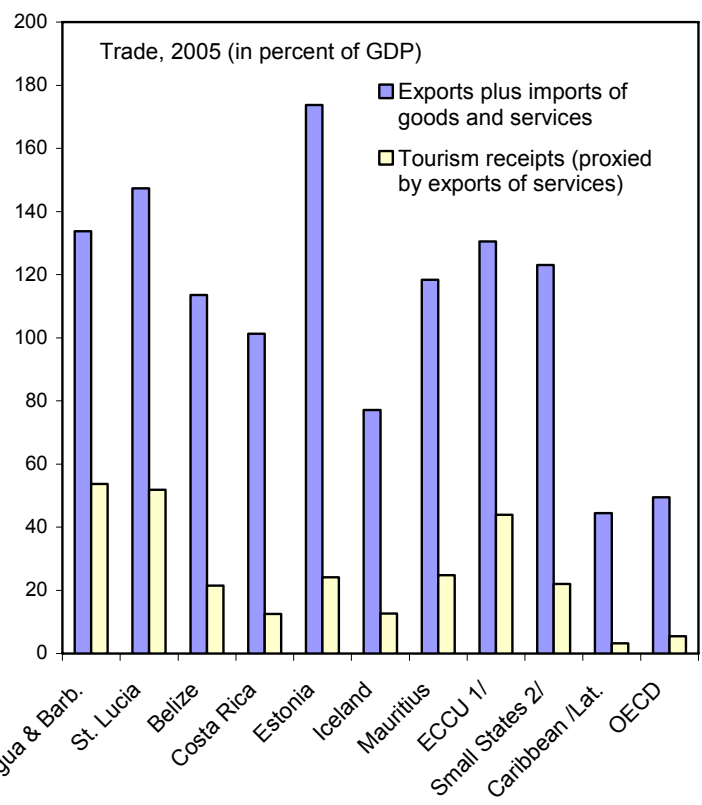

...and social indicators are strong.

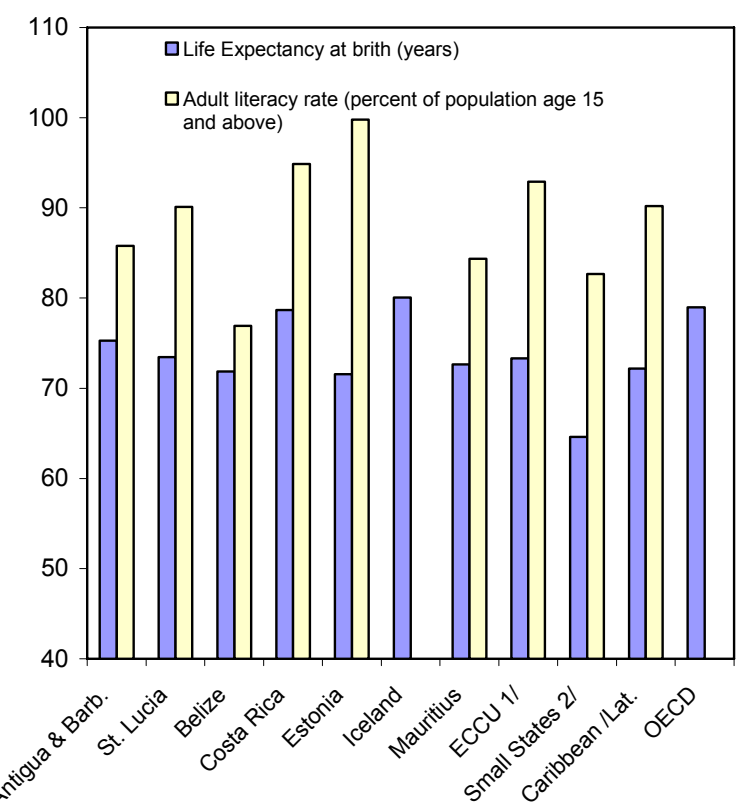

Sources: Country Authorities; IMF, World Economic Outlook, World Bank, World Development Indicators; United Nations, Human Development Indicators; and Fund staff calculations.

1/ ECCU aggregate excludes Anguilla and Montserat.

2/ Small states aggregate includes available data from 38 countries (of the 45 small states defined by the World Bank). 
Figure 2. Antigua and Barbuda: The Macroeconomy

Macroeconomic performance has been good, but there are vulnerabilities.

Strong growth is driven by a construction boom.

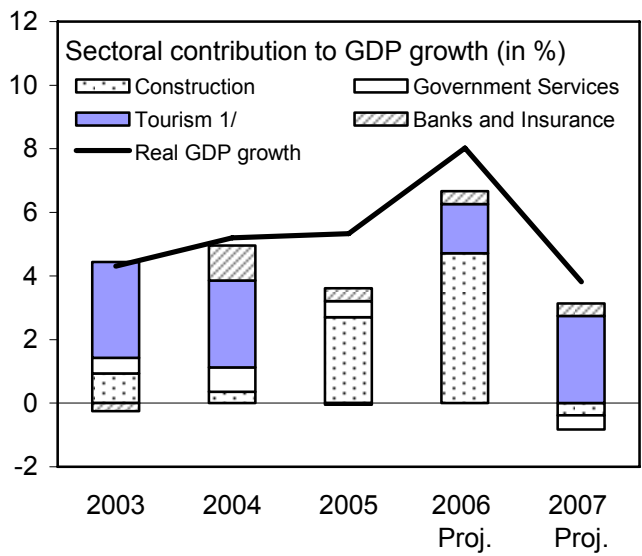

The current acount deficit is widening, financed mainly by FDI inflows.

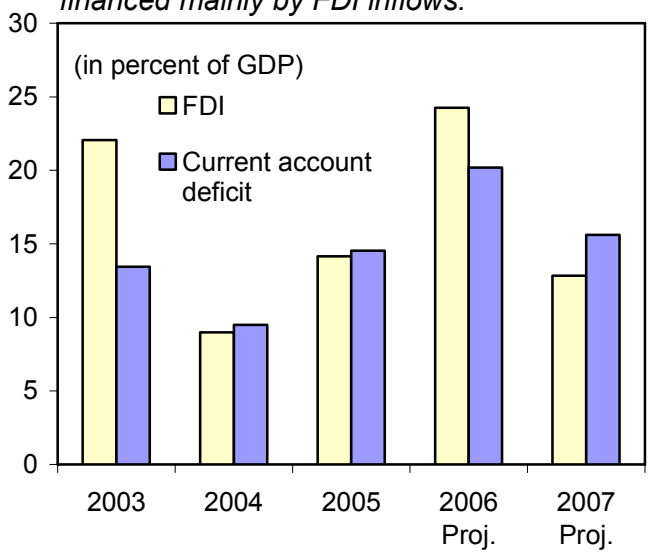

...but inflation is low, although an uptick is expected at the introduction of the VAT.

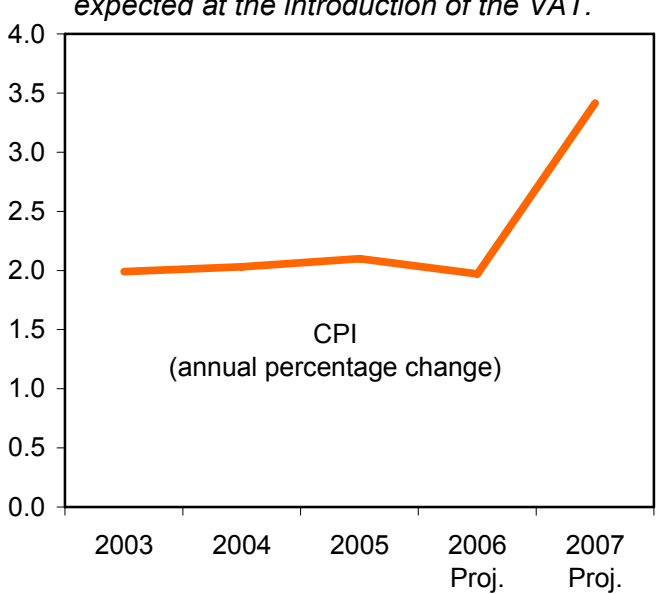

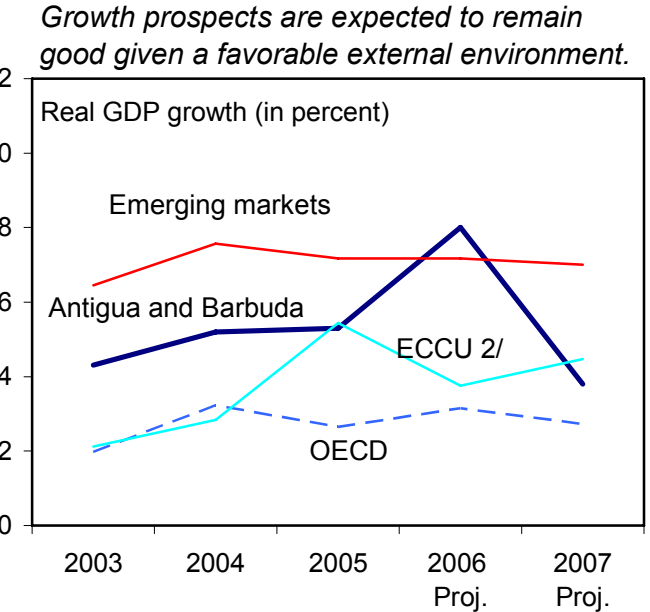

Private sector credit is accelerating...

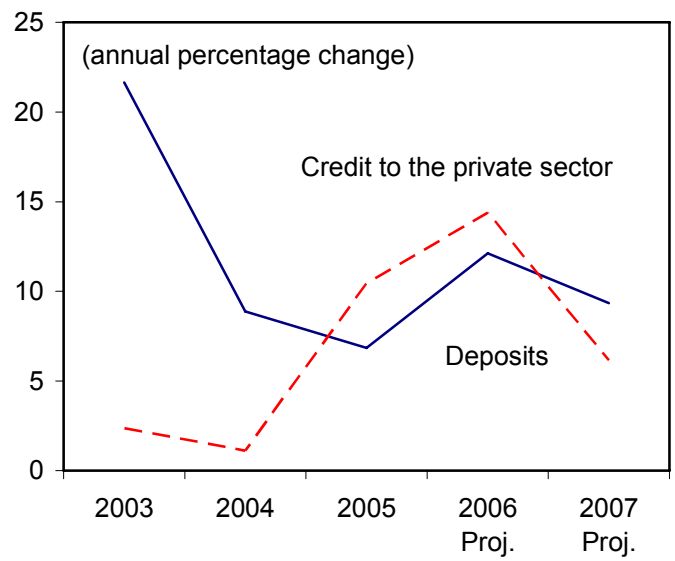

Fiscal imbalances and government debt level

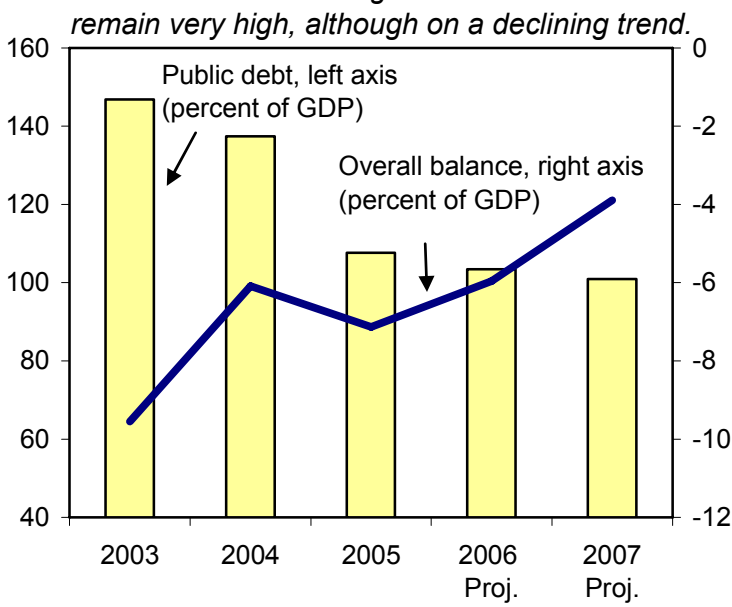

Sources: Antigua and Barbuda Authorities; IMF, WEO; and Fund staff estimates.

$1 /$ Tourism sector includes hotels and restaurants, wholesale and retail trade, and transportation.

2/ ECCU aggregate excludes Antigua and Barbuda. 
Figure 3. Antigua and Barbuda: Banking System Vulnerabilities 1/

Local banks are weaker than foreign-owned banks, and have low asset quality.

Foreign branches have generally been more profitable than local banks...

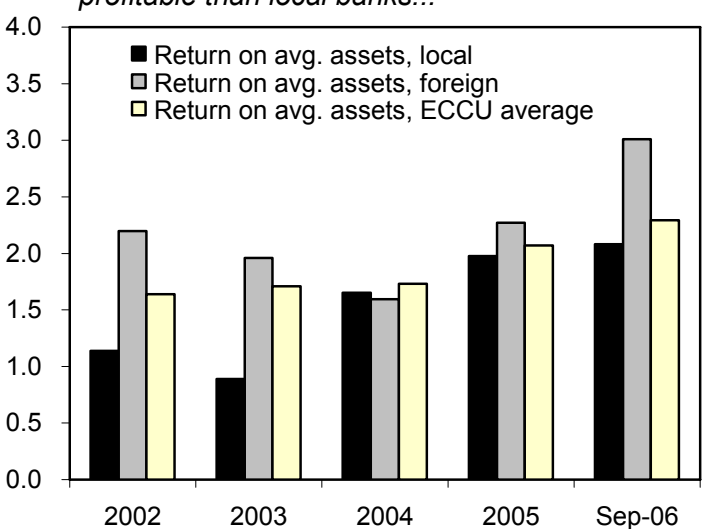

Local banks have higher exposures to the government.

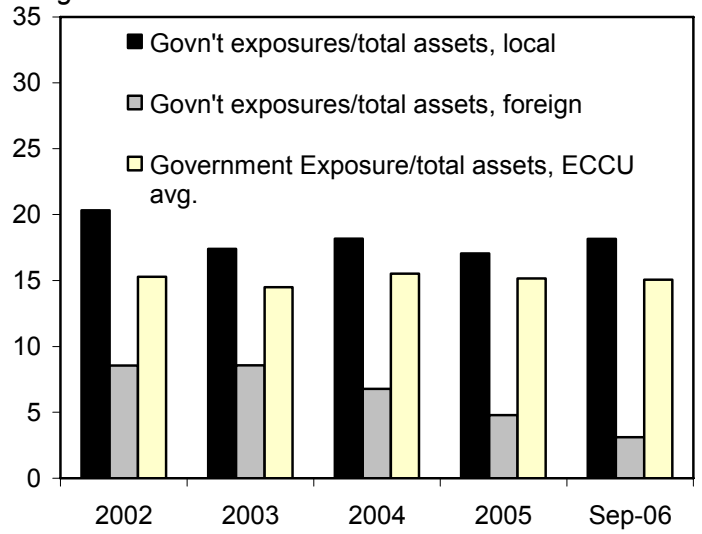

....while provisioning is lower and diverging

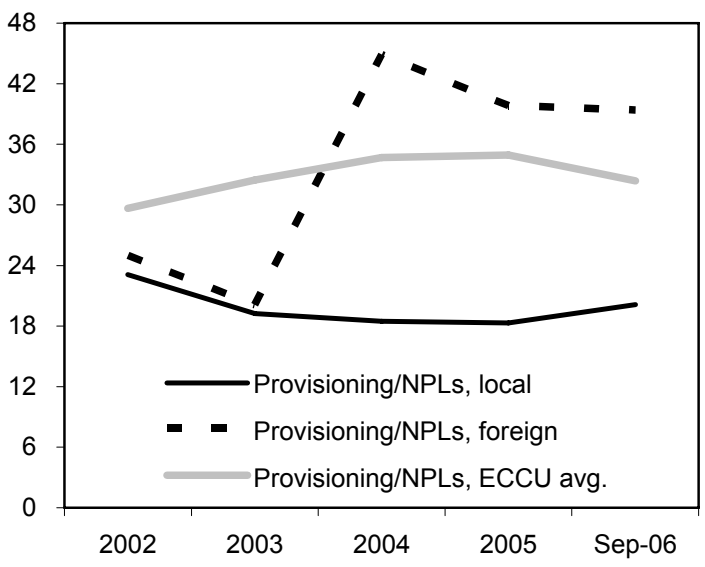

...and relatively more liquid.

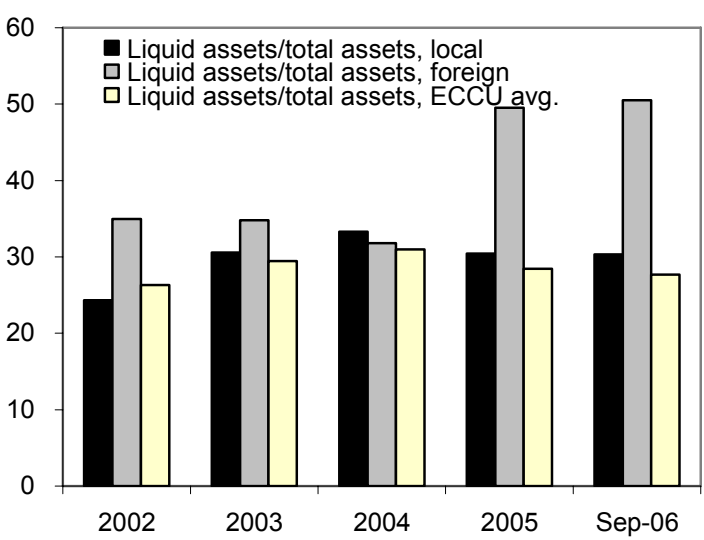

Nonperforming loans remain considerably higher for local banks than foreign banks..

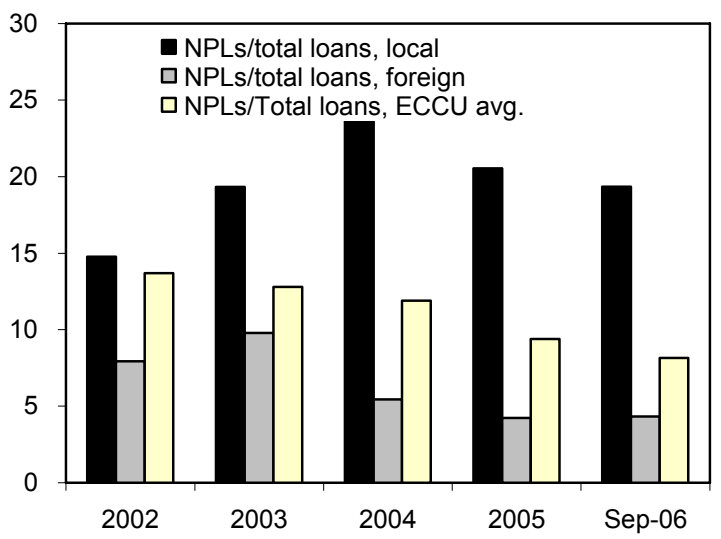

Hence capital adequacy ratios are potentially overstated in local banks.

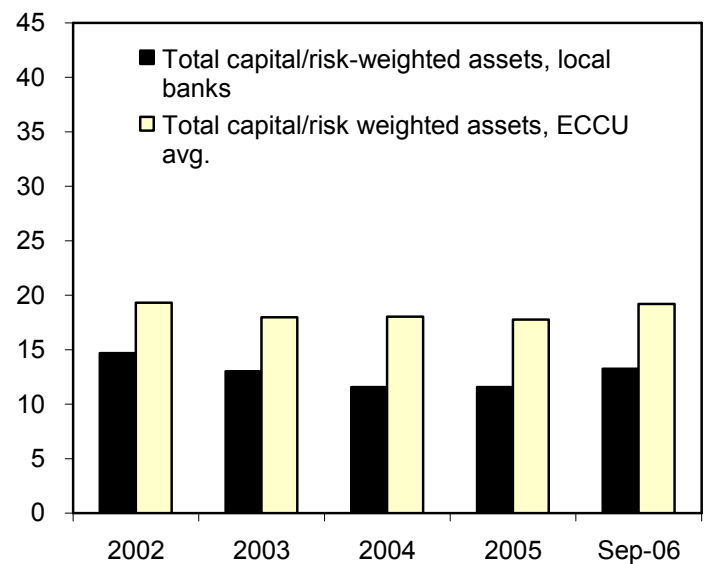

Source: ECCB; and Fund staff calculations.

1/ Prudential indicators are reported by commerical banks, with infrequent onsite verification by the ECCB. 
4. An important fiscal adjustment is underway, but debt remains high and arrears accumulation continues. Fiscal balances improved in the first half of 2006 thanks to tax reforms and collection of tax arrears. However, capital spending, mainly grant-financed and World Cup-related, more than doubled. For the year as a whole, excluding one-off items and assuming spending restraint, the primary balance is projected to improve by over 1 percent of GDP relative to 2005. Nonetheless, the overall budget will remain in substantial deficit.

\begin{tabular}{|c|c|c|c|c|c|c|}
\hline \multirow{3}{*}{$\begin{array}{l}\text { Revenues } \\
\text { Of which } \\
\text { Tax arrears collection }\end{array}$} & \multirow{2}{*}{$\frac{2003}{21.1}$} & \multirow{2}{*}{$\frac{2004}{21.6}$} & \multirow{2}{*}{$\frac{20051 \mathrm{H}}{11.1}$} & \multicolumn{2}{|c|}{$\begin{array}{l}\text { Est. } \\
200520061 \mathrm{H}\end{array}$} & \multirow{2}{*}{$\begin{aligned} \text { Proj. } \\
2006 \\
26.1\end{aligned}$} \\
\hline & & & & 21.8 & 14.5 & \\
\hline & $\cdots$ & $\ldots$ & $\cdots$ & $\ldots$ & 1.3 & 1.3 \\
\hline $\begin{array}{l}\text { Expenditure } \\
\text { Of which }\end{array}$ & 30.7 & 27.7 & 16.0 & 28.9 & 15.9 & 32.1 \\
\hline Wages & 12.3 & 11.4 & 5.1 & 10.7 & 4.9 & 9.9 \\
\hline Goods and services & 4.9 & 5.0 & 2.2 & 4.6 & 1.8 & 4.3 \\
\hline Capital expenditure & 4.0 & 2.5 & 2.0 & 4.0 & 4.2 & 6.5 \\
\hline Payment for severance package & $\ldots$ & $\ldots$ & $\ldots$ & $\ldots$ & $\ldots$ & 2.0 \\
\hline Primary balance & -4.2 & -1.2 & -2.3 & -2.3 & 0.9 & -1.7 \\
\hline Overall balance & -9.5 & -6.1 & -5.0 & -7.1 & -1.4 & -6.0 \\
\hline Memo items: & & & & & & \\
\hline Primary balance excluding one-off items $1 /$ & -4.2 & -1.2 & -2.3 & -2.3 & -0.5 & -1.1 \\
\hline $\begin{array}{l}\text { Government debt } \\
\text { Of which }\end{array}$ & 147 & 137 & $\cdots$ & 108 & 102 & 103 \\
\hline Stock of arrears & 64 & 66 & $\ldots$ & 63 & 62 & 62 \\
\hline
\end{tabular}

Sources: Antigua and Barbuda authorities; and Fund staff estimates.

1/ One-off items in 2006 include collection of tax arrears and the severance pay.

5. Despite widespread arrears and awareness of the impending debt strategy, the government was able, for the first time, to access the regional securities market. In July 2006, it issued two bonds totaling EC\$100 million (5-7 year; 8-9 percent fixed interest) in U.S. and E.C. dollars. Proceeds were used partly to repay expensive debt and set aside for severance costs. Earlier in 2006, the government also issued EC\$51 million in 91-day treasury bills that have since been rolled over.

6. Medium-term growth prospects are good, but subject to risks. Real GDP growth of 4-5 percent is feasible, given the outlook for main tourism markets, the increase in stay-over capacity, and assuming implementation of the authorities' policy agenda. However, labor shortages could constrain growth. The main vulnerabilities relate to:

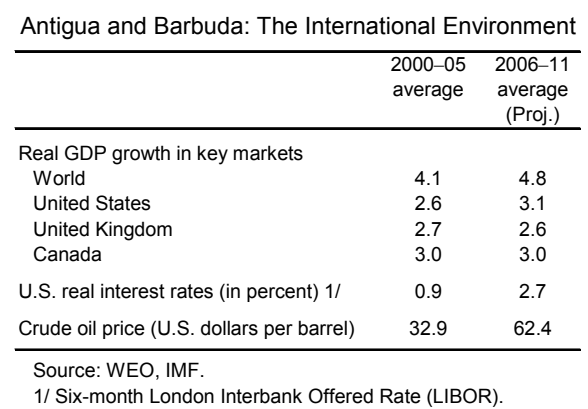


- Tourism downturn. Tourism is vulnerable to shifts in demand from the United States and the United Kingdom, which together account for three-quarters of stay-over arrivals. Avian flu or terrorism could also have severe effects even if Antigua and Barbuda is not hit directly. Policy options are limited, but the authorities are undertaking marketing to broaden the tourism base.

- $\quad$ Hurricanes. Antigua and Barbuda experienced four hurricanes in the 1990 s with varying effects - on average, they were associated with a 2 percent fall in GDP and an 8 percentage point increase in the debt ratio. The authorities have increased disaster management efforts, and have expressed interest in participating in the Bank's Caribbean Catastrophe Risk Insurance project.

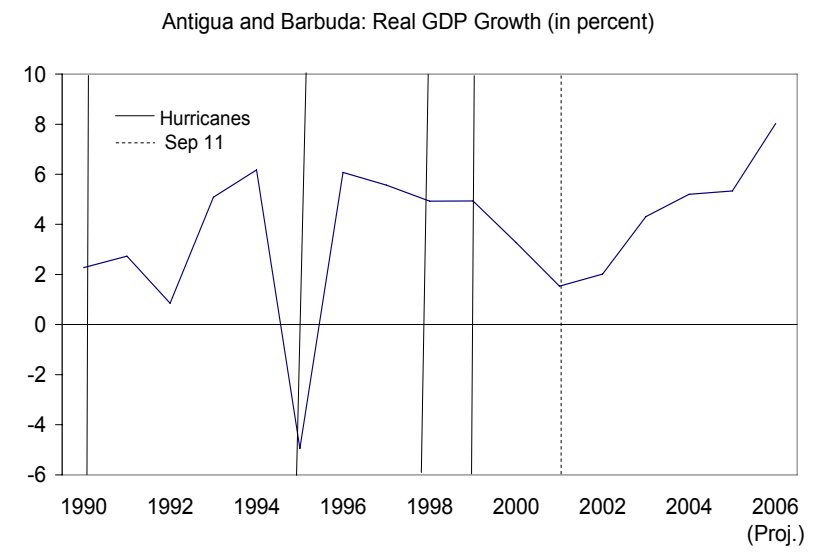

- $\quad$ Policy risk. Slippages in the reform agenda could thwart prospects for sound public finances and debt sustainability, sap investor confidence, and undermine growth prospects. Risks of slippage will rise as the 2009 elections nears.

7. The authorities broadly shared staff's views and projections, but thought growth would be higher in 2006. They expect growth in 2006 to be about 12 percent, based on faster completion of large construction projects, followed by a more pronounced slowdown in 2008. Their fiscal projections were broadly in line with those of the mission as much of the construction-driven growth is tax exempt. It was agreed that frontloading the reforms, to take advantage of the strong near-term growth outlook, would provide best assurances that reforms would not be blown off course.

\section{Policy Discussions}

8. A central theme of the discussions was reforms to restore sound public finances and sustain economic growth. These objectives are interlinked: high growth facilitates fiscal adjustment, while strong public finances strengthens growth prospects by providing buffers against shocks and by reducing uncertainty over future taxation and provision of public services. The authorities' program was designed with assistance from CARTAC and benefited from technical assistance from the Fund.

\section{A. Restoring Sound Public Finances}

9. The authorities' have launched a comprehensive reform agenda to restore sound public finances and achieve debt sustainability. It involves a sizeable fiscal adjustment, regularization of relations with creditors, and exploration of all financing options, including a debt strategy, to ensure progress toward debt sustainability. 
10. Implementation of reforms underway would substantially improve the primary balance. The authorities were still at an early stage of preparing for the 2007 budget, but with successful implementation of reforms underway and firm expenditure control, a primary surplus - the first in nine years - of close to 1 percent of GDP would be a feasible and ambitious target. It would imply a 3 percent of GDP improvement over 2005. The primary surplus would rise further to 4 percent of GDP by 2011 (Tables 4-5).

11. Any improvement will require progress on several fronts. There have been delays in introducing the VAT and completing civil service retrenchment, revenue administration is weak, compliance with the personal income tax has been uneven (averaging only 30 percent in some segments), and holding back spending is a constant challenge.

\section{Recognizing the challenges to implementation capacity, the immediate fiscal} priorities should be:

- $\quad$ Complete the voluntary separation program. This program is now expected to be completed in 2007, yielding wage savings of 2 percent of GDP relative to 2005.

- $\quad$ Ensure a successful VAT. The VAT and excises are projected to provide 3 percent of GDP in additional revenue by 2011 , but this hinges on successful implementation and avoidance of exemptions. The authorities are considering options to strengthen VAT implementation capacity and thought staff's revenue projections were conservative.

- Improve the personal income tax. Penalties should be enforced to improve compliance. A broader definition of taxable income to include benefits and allowances would reduce tax avoidance.

- $\quad$ Strengthen expenditure control. The fiscal adjustment depends on holding average spending growth below two percent a year in real terms, requiring firm control over commitments, including the wage bill. The authorities expect expenditure control to be boosted by the new cash management system and the new Finance, Audit, and Administration Act, and fuller integration of the Public Sector Investment Program (introduced in 2005) into the budgetary process to ensure careful evaluation of all public investments. The mission urged that social programs be preceded by detailed analysis, drawing on the ongoing poverty assessment. 
13. However, even with this fiscal adjustment, large financing requirements remain and debt sustainability would not be assured. The overall budget deficit and debt dynamics depend on the terms on which government arrears will be regularized, and the availability and terms of new financing to close financing gaps.

\section{The authorities are considering} options to close financing shortfalls and move toward debt sustainability. They are developing a strategy with their advisors to regularize arrears and bring debt to a more manageable level, but noted the challenges from the heterogeneity of the debt, pervasive earmarking, and the uncertain status of certain large loans (Table 6) complexities not faced by recent debt operations in the ECCU. ${ }^{2}$ The authorities are also considering seeking further market borrowing and concessional donor financing-including the PetroCaribe agreement with Venezuela, which would provide a concessional loan (1-2 percent) to finance a portion of oil imports from Venezuela. The mission encouraged the authorities to explore also other options, including privatization receipts.

\section{The mission prepared an illustrative} baseline scenario to assess debt sustainability (Tables 7-8, Figures 4 and 7, and Box 2). Government debt would decline gradually to the 60 percent of GDP benchmark established by the ECCB's Monetary Council for 2020. However, the debt will remain high, and its path remains vulnerable to shocks and sensitive to financing assumptions. If more favorable financing terms are obtained (e.g., 3 percent real interest rate) on new financing or through

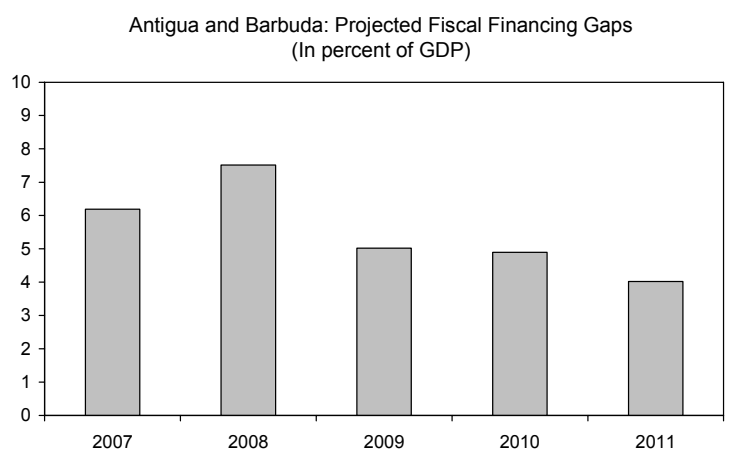

Antigua and Barbuda: Primary Balance and Debt Service Projections

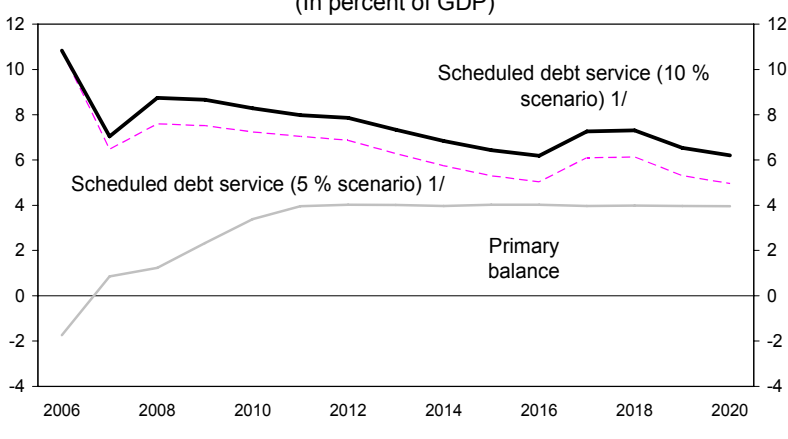

$1 /$ Includes (i) scheduled interest and amortization of the external debt, (ii) interest on domestic debt; and (iii) interest on the assumed regularization instrument. (In percent of GDP) 
negotiations with creditors, the debt ratio would decline more definitively, to around 50 percent of GDP by 2020. An important risk relates to policy slippages, as illustrated in the mission's "slow-reform"scenario. Finally, the baseline scenario, despite achieving a declining debt ratio, involves substantial financing requirements, especially in 2007-09, and unless these are closed, arrears accumulation will continue.

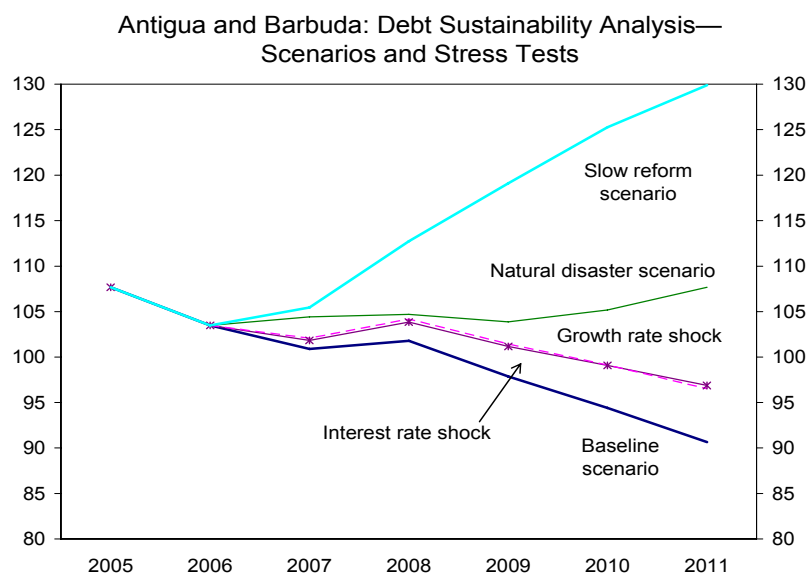

Antigua and Barbuda: Public Sector Debt Sustainability 1/

(In percent of GDP, unless indicated otherwise)

\begin{tabular}{|c|c|c|c|c|c|c|c|}
\hline & \multicolumn{7}{|c|}{ Projections } \\
\hline & 2006 & 2007 & 2008 & 2009 & 2010 & 2011 & 2020 \\
\hline & \multicolumn{7}{|c|}{ Slow reform scenario 2 I } \\
\hline Public sector debt stock & 103.5 & 105.4 & 112.7 & 119.1 & 125.2 & 129.9 & 193.2 \\
\hline Debt service (includes interest on the fiscal gap) & 10.8 & 7.3 & 9.4 & 10.0 & 10.5 & 11.0 & 16.2 \\
\hline \multicolumn{8}{|l|}{ Of which } \\
\hline Interest & 4.2 & 5.0 & 7.1 & 7.9 & 8.6 & 9.2 & 16.1 \\
\hline Total revenue and grants & 26.1 & 23.4 & 23.1 & 23.3 & 23.3 & 23.2 & 22.5 \\
\hline Central government primary balance & -1.7 & 0.1 & -1.8 & -1.6 & -1.6 & -1.3 & -1.3 \\
\hline Fiscal financing gap & 0.0 & 7.2 & 11.2 & 11.7 & 12.1 & 12.2 & 17.5 \\
\hline \multirow[t]{2}{*}{ Real GDP growth (percent) } & 8.0 & 3.3 & 0.1 & 2.0 & 2.3 & 2.4 & 2.5 \\
\hline & \multicolumn{7}{|c|}{ Baseline scenario } \\
\hline Public sector debt stock & 103.5 & 100.9 & 101.8 & 97.8 & 94.4 & 90.6 & 59.4 \\
\hline Debt service (includes interest on the fiscal gap) & 10.8 & 7.0 & 8.7 & 8.7 & 8.3 & 8.0 & 6.2 \\
\hline \multicolumn{8}{|l|}{ Of which } \\
\hline Interest & 4.2 & 4.7 & 6.6 & 6.7 & 6.6 & 6.5 & 4.8 \\
\hline Total revenue and grants & 26.1 & 23.4 & 23.3 & 23.8 & 24.4 & 24.6 & 25.3 \\
\hline Central government primary balance & -1.7 & 0.8 & 1.2 & 2.3 & 3.4 & 4.0 & 4.0 \\
\hline Fiscal financing gap & 0.0 & 6.2 & 7.5 & 5.0 & 4.9 & 4.0 & 2.2 \\
\hline \multirow[t]{2}{*}{ Real GDP growth (percent) } & 8.0 & 3.8 & 1.8 & 4.5 & 4.5 & 4.5 & 4.5 \\
\hline & \multicolumn{7}{|c|}{ Baseline scenario (5 percent financing) } \\
\hline Public sector debt stock & 103.5 & 100.3 & 100.1 & 96.4 & 92.0 & 87.5 & 49.8 \\
\hline Debt service (includes interest on the fiscal gap) & 10.8 & 6.5 & 7.6 & 7.5 & 7.2 & 7.0 & 5.0 \\
\hline Of which & & & & & & & \\
\hline Interest & 4.2 & 4.2 & 5.4 & 5.6 & 5.6 & 5.6 & 3.5 \\
\hline Total revenue and grants & 26.1 & 23.4 & 23.3 & 23.8 & 24.4 & 24.6 & 25.3 \\
\hline Central government primary balance & -1.7 & 0.8 & 1.2 & 2.3 & 3.4 & 4.0 & 4.0 \\
\hline Fiscal financing gap & 0.0 & 5.6 & 6.4 & 5.2 & 3.8 & 3.1 & 1.0 \\
\hline Real GDP growth (percent) & 8.0 & 3.8 & 1.8 & 4.5 & 4.5 & 4.5 & 4.5 \\
\hline
\end{tabular}

Sources: Antigua and Barbuda authorities; and Fund staff estimates and projections

$1 /$ Includes gross central government and government guaranteed debt.

2/ Fiscal projections under this scenario are based on the following main assumptions: (i) compliance rate for VAT is constant at 55 percent over the medium-term, (ii) there are no efficiency gains from tax administration over time (iii) wage savings from voluntary separation program are lower than under baseline scenario, and (iv) weaker expenditure control. 
Figure 4. Antigua and Barbuda: Public Debt Sustainability: Bound Tests 1/ (Public debt in percent of GDP)

Under the baseline scenario, public debt will decline gradually, but remain vulnerable to shocks.

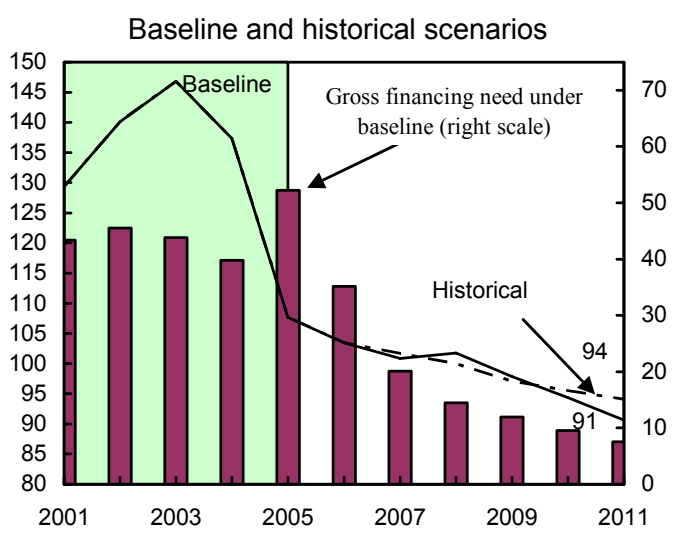

Growth shock (in percent per year)

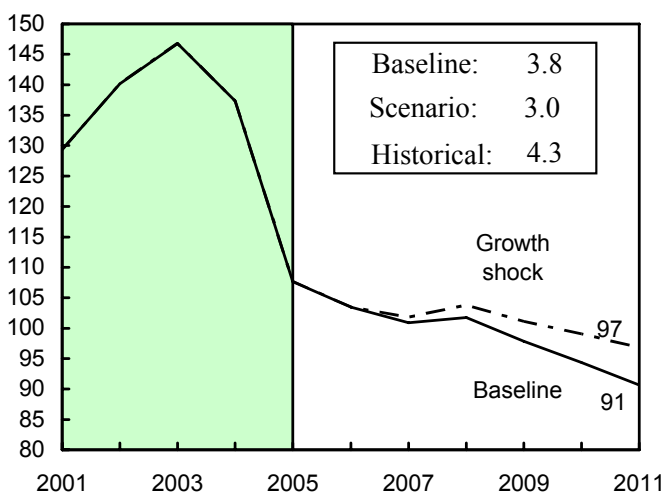

Combined shock 2/

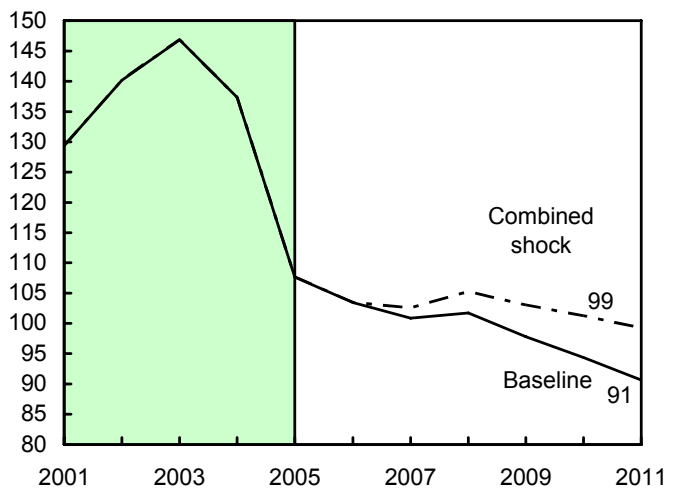

Interest rate shock (in percent)

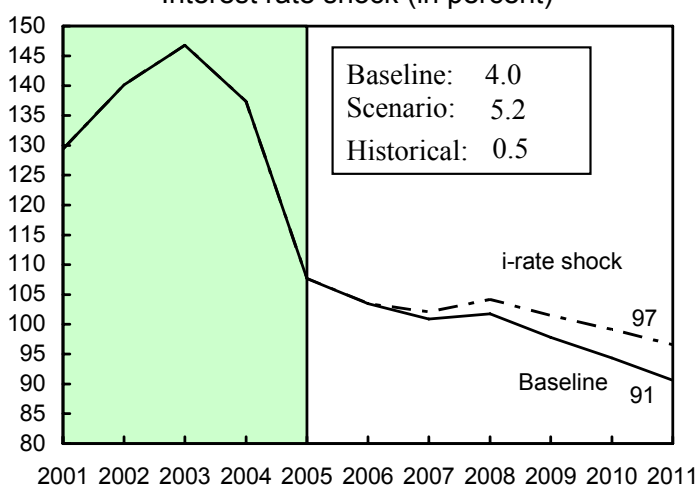

Primary balance shock (in percent of GDP) and no policy change scenario (constant primary balance)

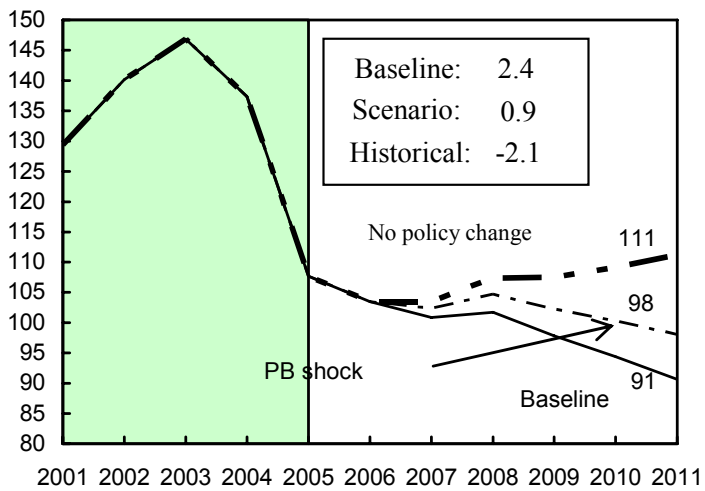

Real depreciation and contingent liabilities shocks 3/

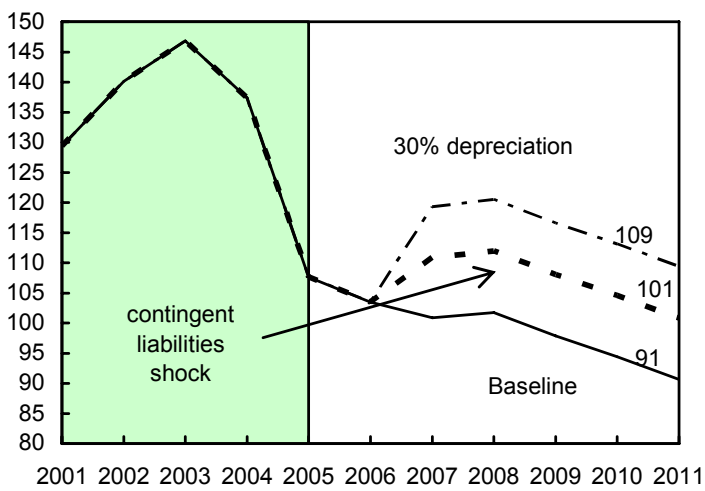

Sources: International Monetary Fund, Country desk data, and Fund staff estimates.

$1 /$ Shaded areas represent actual data.Individual shocks are permanent one-half standard deviation shocks. Figures in the boxes represent average projections for the respective variables in the baseline and scenario being presented. Ten-year historical average for the variable is also shown.

2/ Permanent one fourth standard deviation shocks applied to real interest rate, growth rate, and primary balance. 3 / One-time real depreciation of 30 percent and 10 percent of GDP shock to contingent liabilities occur in 2006, with real depreciation defined as nominal depreciation (measured by percentage fall in dollar value of local currency) minus domestic inflation (based on GDP deflator). 
16. Depending on the outcome of the debt strategy and other financing options, the need for further fiscal effort cannot be ruled out. The mission

supported the intention to regularize arrears and encouraged an open and collaborative approach with creditors. In designing the debt strategy, it will be important to consider the scope and desirability of including earmarked debt, treasury bills, and debts owed to the banking system - paying close attention to the health of domestic banks, given their high exposure to government debt. A 4 percent primary surplus would represent a significant adjustment and hinges on successful implementation of difficult reforms and unrelenting expenditure discipline. Yet, depending on the prospects for closing the gaps, further fiscal

Antigua and Barbuda: Yield from Additional Fiscal Measures (2007-11)

\begin{tabular}{lcc}
\hline & $\begin{array}{c}\text { In EC } \\
\text { million }\end{array}$ & $\begin{array}{c}\text { In percent } \\
\text { of GDP }\end{array}$ \\
\hline & (Average yield per year) \\
Revenue & & \\
$\quad$ VAT & 23 & 0.8 \\
$\quad$ Increase in compliance rate & 10 & 0.3 \\
$\quad$ Uniform rate of 15 percent from 2010 1/ & $7-35$ & $0.2-1.0$ \\
Increase in excise tax on luxury goods & & \\
$\quad$ Property tax reform (move to market & 25 & 0.8 \\
valuation and higher compliance) & 12 & 0.4 \\
$\quad$ Recouping tax arrears & & \\
$\quad$ Expenditure & 15 & 0.5 \\
$\quad$ Civil service retrenchment of 500 in 2007 & 19 & 0.6 \\
$\quad$ Wage savings & 4 & 0.1 \\
$\quad$ Separation package & 14 & 0.4 \\
Civil service pension reform & 5 & 0.1 \\
$\quad$ No minimum pension increase in 2008 2/ & 5 & 0.3 \\
$\quad$ Civil service pension parametric reform 3/ & 9 &
\end{tabular}

Source: Fund Staff estimates

1/ Average annual yield for 2010-11.

2/ The baseline assumes an increase in minimum pensions in 2008. Average annual yield from this reform for 2008-11.

3/ Savings reach 2 percent of GDP by 2020. adjustment might be needed. In discussing possible fiscal measures, given the tax reforms underway and the already rather high tax burden, the mission emphasized expenditure reforms - a second civil service downsizing, and pension reform - and improved tax administration.

\section{Any assessment of public finances should cover the broader public sector.}

Partial data indicate that the non-central government public sector is almost as large as the central government (Table 9). The weak expenditure management of the broader public sector is a concern-for instance, while the central government was downsizing, entities such as the Public Utilities Authority were expanding. Information and control of public finances will be strengthened by the revised Finance, Administration, and Audit Act. The mission also encouraged a review of the composition and modalities for providing public services, especially

\begin{tabular}{lcc}
\multicolumn{3}{c}{$\begin{array}{c}\text { Antigua and Barbuda: Size of the Government, } \\
\text { (In percent of GDP) }\end{array}$} \\
\hline $\begin{array}{c}\text { Central } \\
\text { Government }\end{array}$ & $\begin{array}{c}\text { Broader } \\
\text { Public Sector 1/ }\end{array}$ \\
\hline Revenue & 21.8 & 41.9 \\
Expenditure & 28.9 & 43.0 \\
of which: wage bill & 10.7 & 13.4 \\
Overall balance & -7.1 & -1.1 \\
Primary balance & -2.3 & 4.1 \\
Memorandum item & & \\
Debt 2/ & 107.7 & 77.5
\end{tabular}

Sources: Antigua and Barbuda authorities; and Fund staff estimates 1 / Includes the central government, statutory bodies, and three public sector enterprises.

2/ Broader public sector debt nets out intra public sector debt. in education and health. 
18. The mission welcomed plans to reform pensions under the universal scheme (ABSSS), but urged that these also include the civil service pension scheme.

Demographic changes (see below) will cause rising pension expenditures for both schemes over the medium term. A draft White Paper discusses options for ABSSS pensions, including raising the retirement age and contribution rates, and reducing benefit levels. These options mirror those in recent Fund technical assistance. The mission agreed that reforms to the ABSSS should be accompanied by the government starting to pay its contributions to the scheme. It also suggested to reform ABSSS pensions along with civil service pensions, and to consider integrating Antigua and Barbuda: Social Security System Expenditures and Contributions,

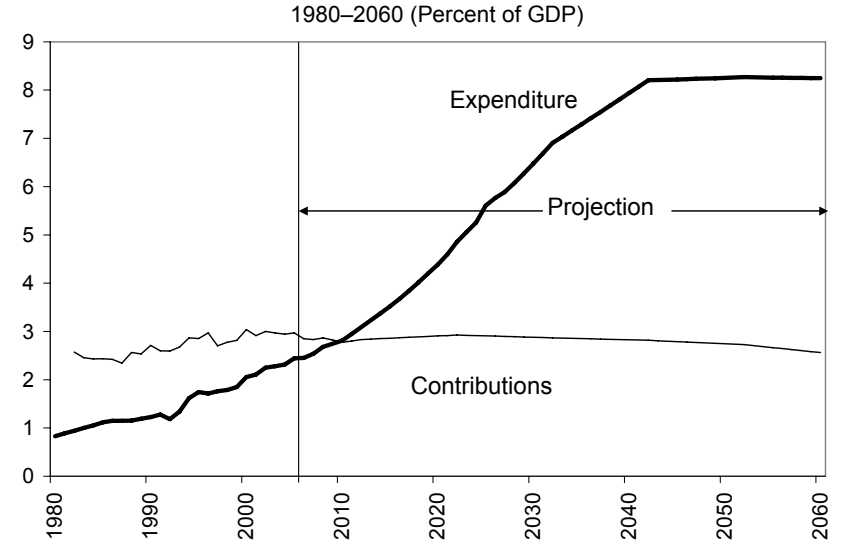

Source: Roach., S., 2006, "Social Security Systems in the Eastern Caribbean Currency Union," ECCU Selected Issues Paper. the two schemes.

19. The authorities consider moving to a flexible petroleum pricing mechanism. Currently, gasoline retail prices are fixed, and increases in the international price reduces the consumption tax revenue. The authorities raised retail prices by 40 percent in October 2005 to restore taxes. A flexible pricing mechanism would remove distortions in the price structure and shield the budget from oil price

ECCU: Price of Regular Gasoline, August 2006 (US\$ per US gallon)

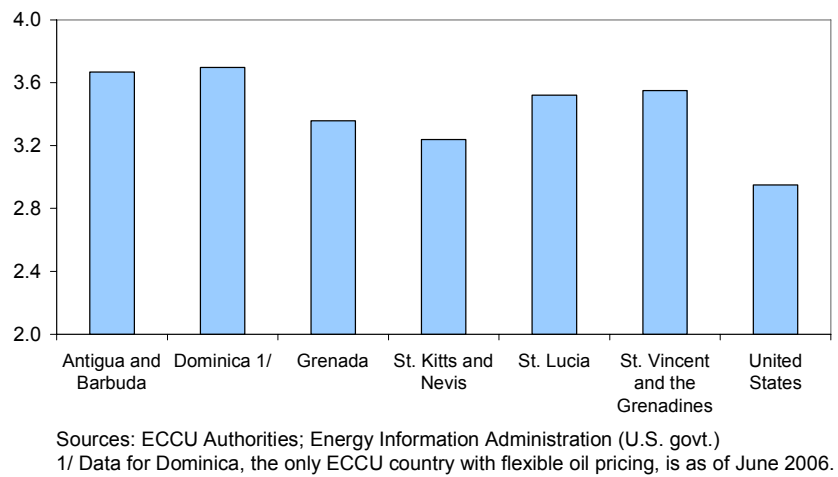

fluctuations.

\section{B. Sustaining Growth}

20. A key challenge is how to sustain growth in the face of adverse demographic dynamics. World Bank projections show a stagnant workingage population and a rising number of people at retirement age over the next decade. Sustaining per capita income growth under such conditions will require growth in output-per-worker and/or continued inflows of foreign workers.
Antigua and Barbuda: Population by Age Group (In 1,000s)

\begin{tabular}{lcc}
\hline & 2005 & (Proj.) \\
& 2015 \\
\hline Youth (0-14) & 16 & 17 \\
Working age (15-59) & 50 & 50 \\
Retirement age (60+) & 9 & 13 \\
Total & 75 & 80 \\
\hline
\end{tabular}

Source: World Bank. 
21. A stagnant working-age population and labor shortages pose challenges for labor market policy. The authorities are concerned about unemployment, especially among the young, and the challenge of finding the right balance of foreign workers in the work force. Foreign labor has supported the current economic expansion by reducing labor shortages. Going forward, reform of regulations, including for dismissals, could increase labor market flexibility and improve the business environment (Figure 5). Unemployment, and skills-mismatches in key sectors, could be reduced by encouraging the establishment of accredited institutions that can provide certification. This would also enable Antiguans to take advantage of opportunities within the CARICOM Single Market. ${ }^{3}$ Finally, the ongoing civil service downsizing could help reduce labor shortages.

\section{External competitiveness, though hard to gauge, will be bolstered by hotel and} infrastructure investments, and improvements in the business environment (Figure 6). The real effective exchange rate has depreciated since 2002, with the weakening of the U.S. dollar against world currencies. Even so, the current account deficit has widened, reflecting a surge in FDI. Antigua and Barbuda is a high-cost tourism destination and there is some uncertainty over how tourism will respond to the expansion in hotel capacity given similar expansions elsewhere in the region. Industry representatives are generally optimistic though, pointing to high occupancy rates, which had constrained the country's capacity to maintain market share. The mission agreed that competitiveness is best buttressed through reforms to raise productivity and upgrade the infrastructure. In this connection, efforts to streamline the public sector and revamp the tax system, and implementation of the Investment Authority Act - approved in August 2006 to simplify procedures-will support competitiveness and growth prospects. Also, the CARICOM Single Market will widen employment, trade, and business opportunities.

\section{The internet gaming sector, once a source of jobs and diversification from}

tourism, is collapsing. The authorities indicated that employment in this sector has fallen from some 3,500 people to 700 after the loss of access to the market in United States, and the outlook for the sector took a turn for the worse in the fall of 2006 after new U.S. legislation curtailed internet gaming further. The authorities expressed frustration that an amicable solution to the dispute could not be found, even after the World Trade Organization ruled in their favor. The report of an arbitration panel reviewing the United States' compliance with WTO rulings is expected in early 2007.

24. There is scope to make tax incentives for investment less costly and distortionary. Like many countries in the region, Antigua and Barbuda uses tax concessions - mainly under the corporate income tax, import duties, custom service charge,

\footnotetext{
${ }^{3}$ CARICOM stands for the Caribbean Community. Antigua and Barbuda joined the Single Market in June 2006.
} 
Figure 5. Antigua and Barbuda: Comparative Business Environment

\section{Overall, Antigua and Barbuda's business environment is competitive, but with some areas of concern.}

Antigua and Barbuda is ranked 33rd out of 175 economies in the overall cost of doing business 1/

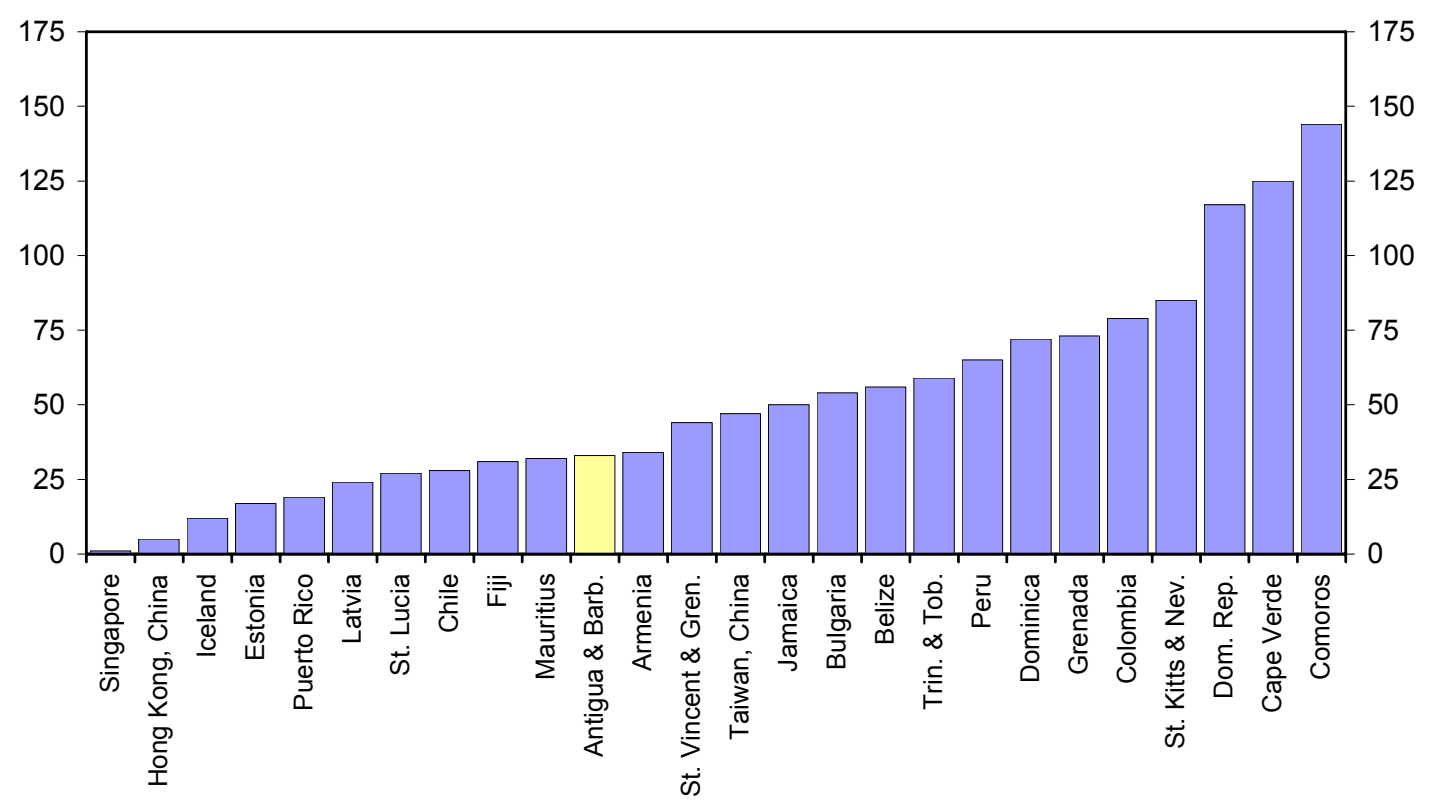

But the cost of dismissals is high...

$\ldots$ as is the statutory tax rate
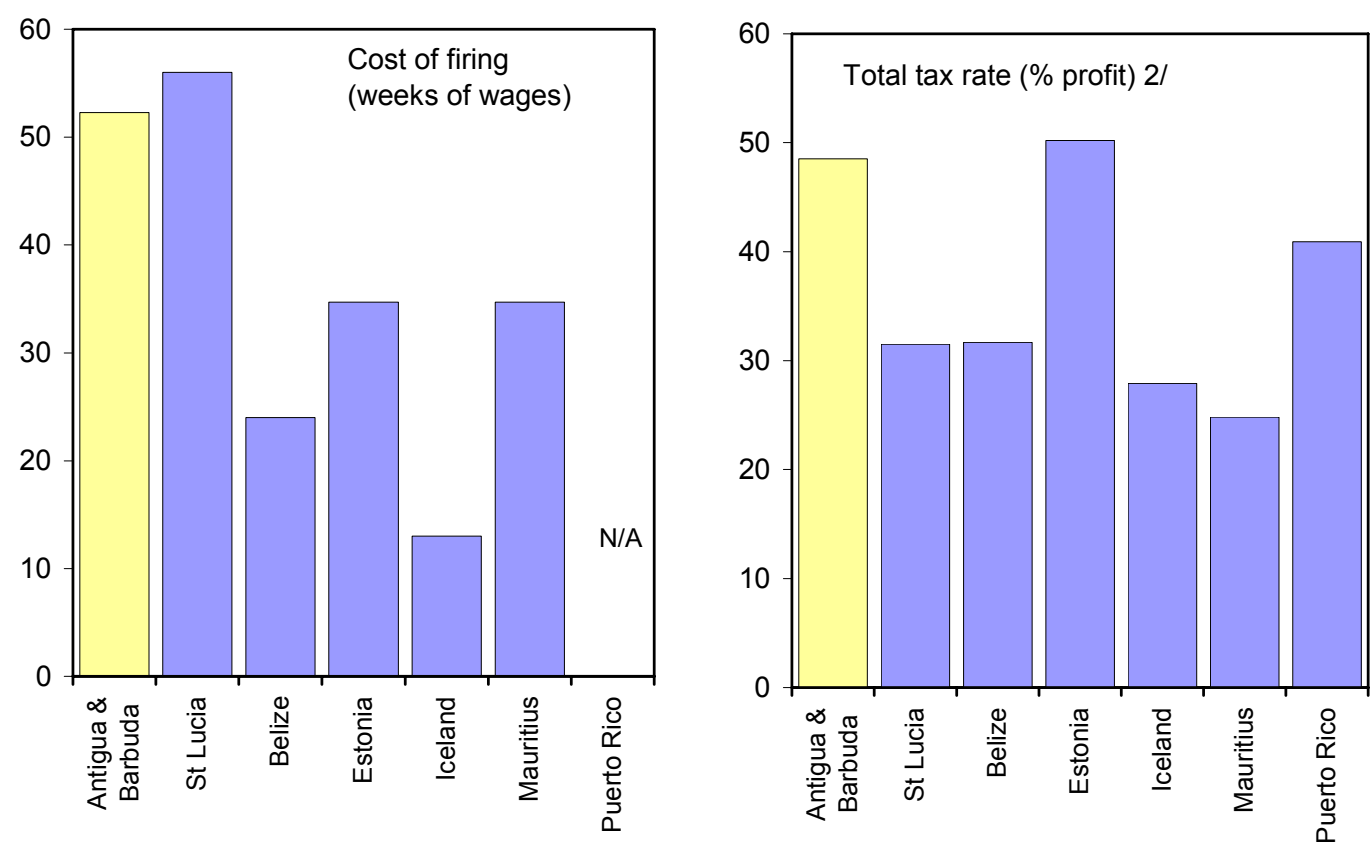

Sources: "Doing Business," World Bank, IFC, and USAID (August 2006).

$1 /$ Rank among 175 economies, where 1 is most conducive and 175 is least conducive.

2/ For fiscal year 2005. The taxes included can be divided into five categories: corporate income tax, social security contributions and other labor taxes paid by the employer, property taxes, turnover taxes and small taxes (such as municipal fees and vehicle and fuel taxes). 
Figure 6. Antigua and Barbuda: External Competitiveness, 1992-2006

Available indicators of external competitiveness show a mixed picture.

While the CPI-based real effective exchange rate (REER) has depreciated since $2002 \ldots$

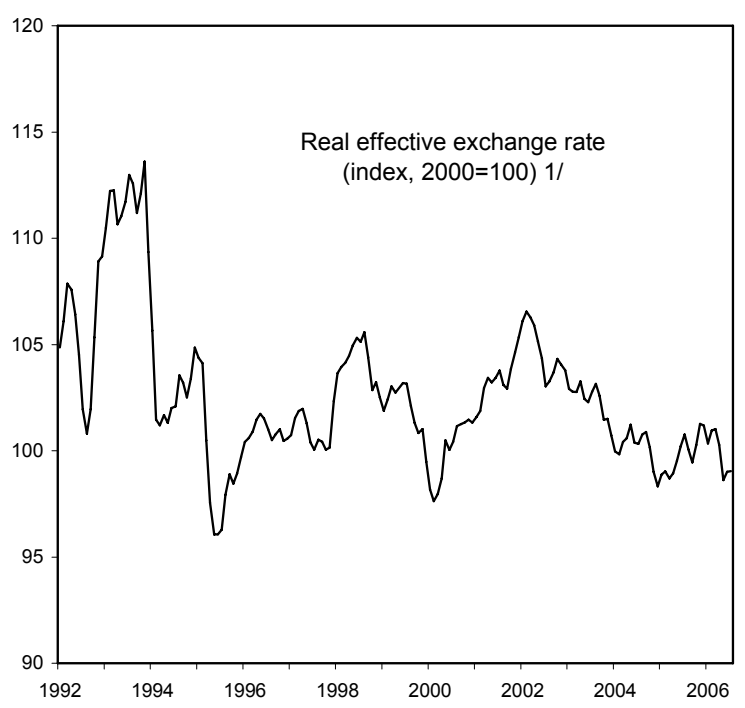

... Antigua and Barbuda remains a high-cost destination relative to the wider Caribbean and other competitors...

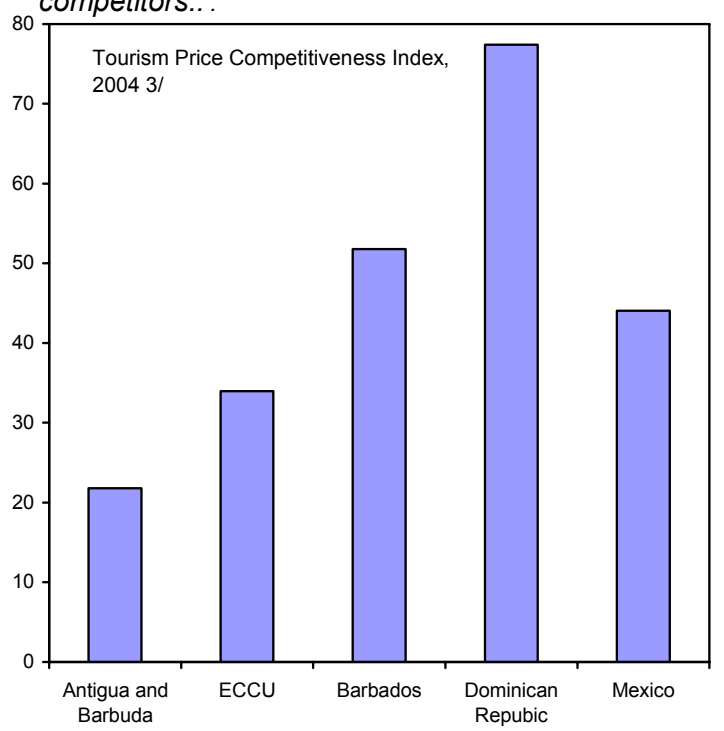

....and in the tourism sector, a customer-based measure of the REER has also depreciated considerably...

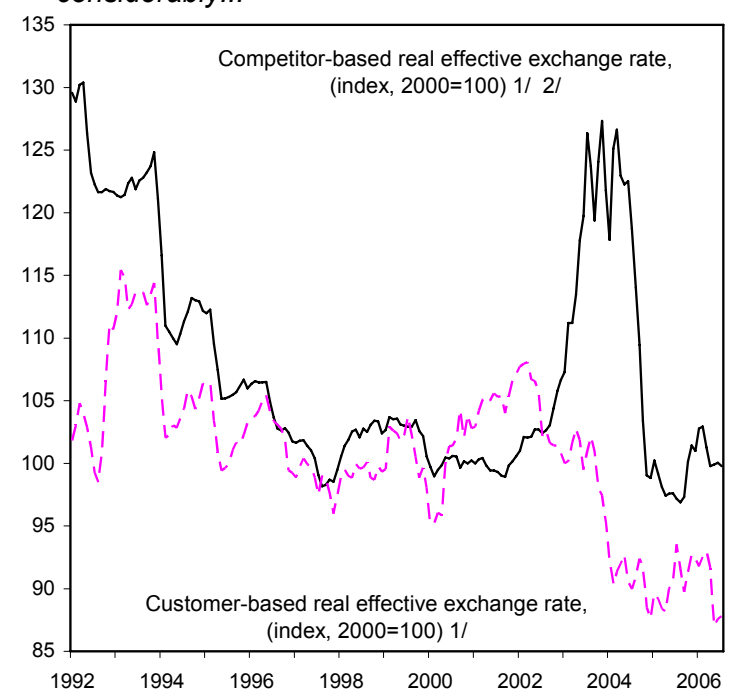

...and its share of stay-over arrivals in the Caribbean has been declining, as other markets have grown faster.

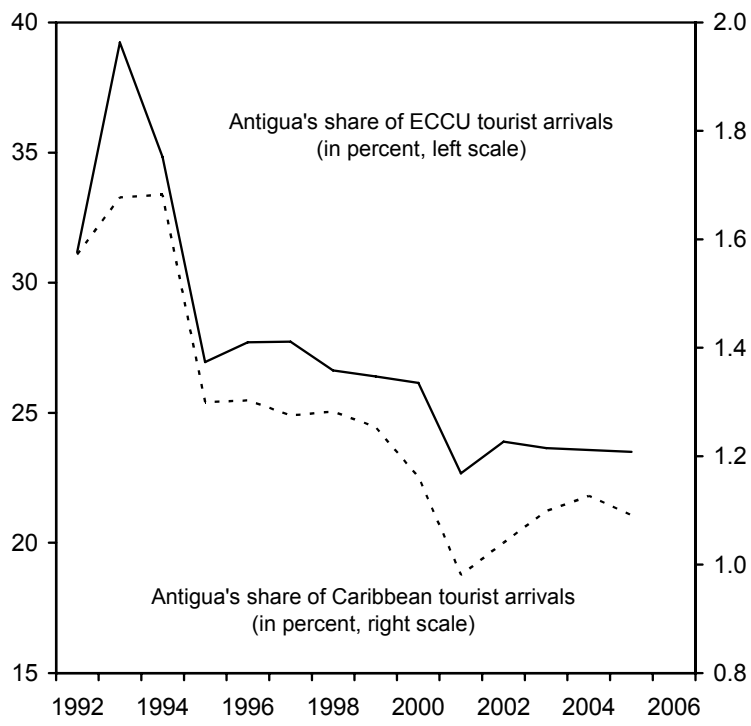

Sources: Eastern Caribbean Central Bank; Caribbean Tourism Organization; ECCU country authorities; ECCU National Insurance Schemes; World Travel and Tourism Council; and Fund staff estimates.

$1 /$ An increase (decrease) indicates an appreciation (depreciation). Customer REER measures customers-weighted index of nominal exchange rates deflated by seasonally adjusted relative consumer prices.

2/ The sharp movements in the competitor-based real exchange rate in 2002-04 were largely driven by the Dominican Republic's peso.

3 / Scaled from 1 to 100 . A higher value means that the country is more competitive in the tourism market. 
and property tax - to attract investment. Concessions, and how they are granted, raise governance concerns, distort the tax system and the trade regime, and imply large fiscal costs. The authorities thought incentives important, and that tax competition with other countries make unilateral reforms difficult. The mission encouraged the authorities to explore a regional approach to tax incentives, noting that, given the large hotel investments underway, time is opportune to consider more efficient alternatives, like accelerated depreciation and timelimited loss carry-forward provisions. The authorities' intentions to cap concessions, and implementation of the Investment Authority Act - that will establish criteria for granting concessions - would make the concession regime more transparent and less discretionary.

\section{Staff Appraisal}

25. An important start has been made in tackling long-standing fiscal and debt problems, and improving growth prospects. Fiscal reforms have been implemented, or are underway, to substantially raise the primary surplus to 4 percent of GDP over the medium term; an Investment Authority Act has been approved to strengthen the business environment; outreach efforts have broadened to explain reforms; and increased confidence in the direction of policies has allowed the government to access the regional capital market.

\section{Economic policies could help sustain growth and competitiveness over the medium}

term. In particular, labor policy can contribute to sustaining growth - in the context of a stagnant domestic workforce - by reducing the costs of dismissals, encouraging programs to reduce skills mismatches, and allowing inflows of foreign workers (e.g., embracing labor mobility under the CARICOM Single Market). The investment incentive system could be improved by moving to a more transparent, rules-based mechanism. External competitiveness could be buttressed by reforms to enhance the business environment, reduce labor market rigidities, and improve basic infrastructure.

27. Major challenges remain in securing a lasting improvement in public finances. First, achieving a primary surplus of 4 percent of GDP over the medium term, while feasible, would be very ambitious and entail a substantial revenue effort and unwavering expenditure control. The priority should be to complete the civil service separation program without further delay, ensure a successful implementation of the VAT as planned, improve tax administration, and strengthen expenditure management and control. Second, despite this adjustment, the debt burden and financing requirements would remain high and vulnerable to shocks. The authorities are exploring all options to close the financing gaps. In its debt strategy, the authorities are encouraged to maintain a collaborative approach to creditors. Depending on the availability and terms of new financing (including from the debt strategy), further fiscal adjustment cannot be ruled out. With the 
completion of tax reforms and given high statutory tax rates, fiscal efforts should focus on the expenditure side. With strong growth and labor shortages, there is scope for a second (but targeted) civil service downsizing. Efforts should also focus on continuing to strengthen tax administration, minimizing losses from tax incentives, and expenditure consolidation at all levels of the government. Effective implementation of the Finance, Administration, and Audit, and Procurement Acts will be critical in sustaining strong public finances.

28. The intention to reform the universal pension scheme is welcome. The next step should be to adopt a plan to reform both ABSSS and civil service pensions, as pressures on both will grow over the medium term, and consider merging the two schemes.

29. Economic statistics need to be improved. Data deficiencies compromise the quality of policy analysis and design. The authorities' efforts to reorganize the Statistics department to improve comprehensiveness, timeliness, and quality of data are welcome.

30. Antigua and Barbuda is proposed to remain on the 12-month Article IV consultation cycle. 
Table 1. Antigua and Barbuda: Basic Data

Area (sq. km)

Arable land (percent of land area)

Population (2001)

Total (thousand)

Annual rate of growth, 1991-2001

(percent a year)

Density (per sq. km.)

GDP per capita (US\$), 2004

Population characteristics (1999)

Life expectancy at birth (years)

Crude birth rate (per thousand)

Crude death rate (per thousand)
I. Social and Demographic Indicators

$\begin{array}{rlr}443 & \text { Health (most recent year) } & \\ 27.3 & \text { Population per physician } & 274 \\ & \text { Population per hospital bed } & 164 \\ 75 & & \\ & \text { Education (2001; in percent) } \\ 1.0 & \text { Adult literacy rate } \\ 171 & \text { Energy (2005; in millions of US\$) } \\ 10,317 & \text { Imports of petroleum products } \\ & \text { Exports of petroleum products } \\ 75 & \text { GDP (2005) } \\ 19 & \text { (in millions of EC\$) } \\ 8 & \text { (in millions of US\$) }\end{array}$

(in millions of US\$)

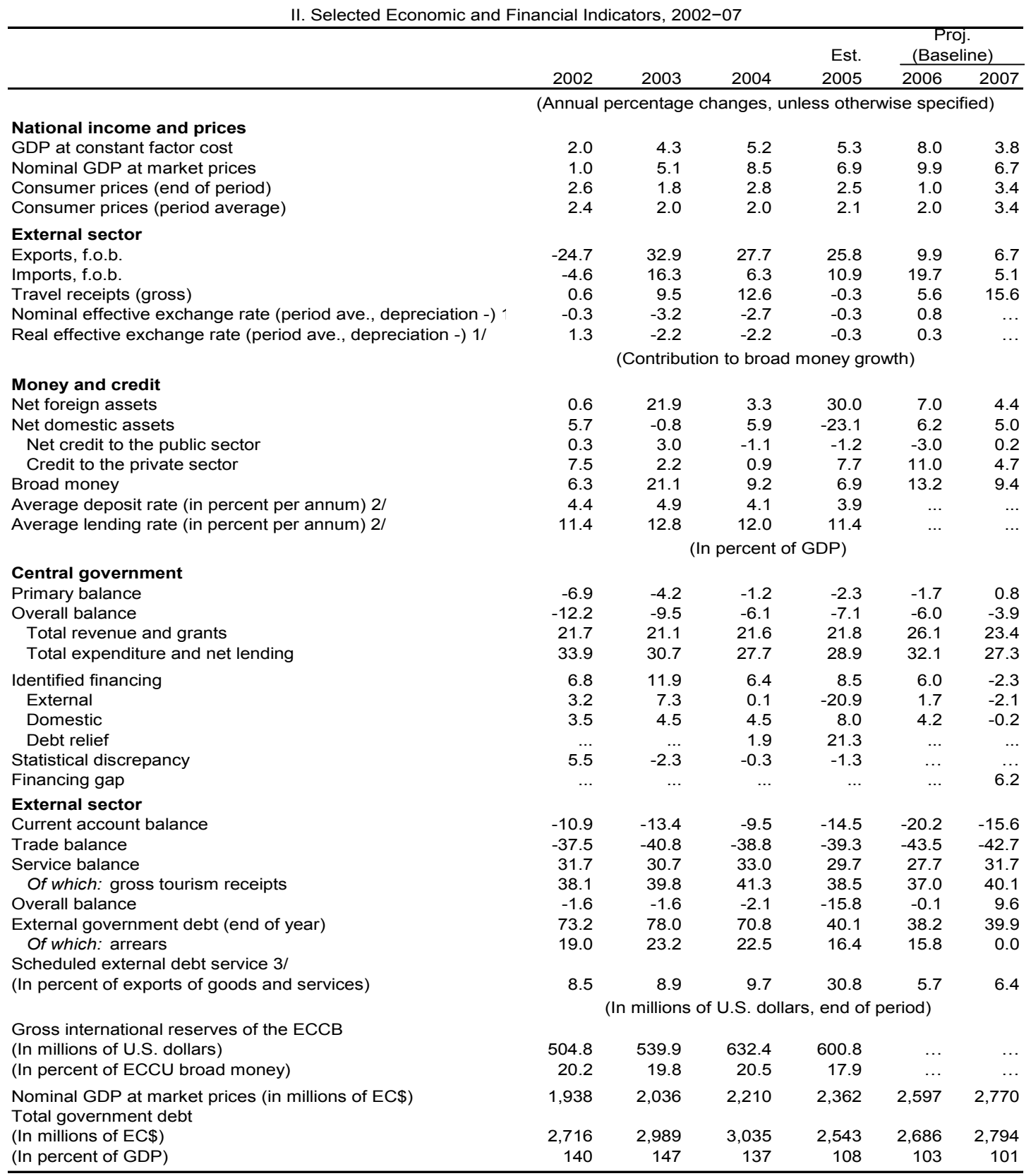

Sources: Antigua and Barbuda authorities; Eastern Caribbean Central Bank; and Fund staff estimates and projections.

1/ Data for 2006 is up to August 2006.

$2 /$ There is a break in the interest rate series in 2003 , owing to changes in reporting requirements for banks.

3/ Data for 2005 includes debt relief from Italy. 
Table 2. Antigua and Barbuda: Monetary Survey

\begin{tabular}{|c|c|c|c|c|c|c|c|c|}
\hline & \multirow[b]{2}{*}{2002} & \multirow[b]{2}{*}{2003} & \multirow[b]{2}{*}{2004} & \multirow{2}{*}{$\begin{array}{l}\text { Sept. } \\
2005 \\
\end{array}$} & \multirow[b]{2}{*}{2005} & \multirow{2}{*}{$\begin{array}{l}\text { Sept. } \\
2006\end{array}$} & \multicolumn{2}{|c|}{$\begin{array}{c}\text { Proj. } \\
\text { (Baseline) } \\
\end{array}$} \\
\hline & & & & & & & 2006 & 2007 \\
\hline & \multicolumn{8}{|c|}{ (In millions of Eastern Caribbean dollars, at end of period) } \\
\hline Net foreign assets & 329 & 668 & 730 & 572 & 1343 & 1452 & 1496 & 1605 \\
\hline ECCB imputed reserves & 237 & 307 & 324 & 299 & 344 & 325 & 369 & 397 \\
\hline Commercial banks' net foreign assets & 92 & 361 & 405 & 273 & 999 & 1127 & 1127 & 1208 \\
\hline Net domestic assets & 1216 & 1203 & 1313 & 1541 & 841 & 913 & 976 & 1099 \\
\hline Net credit to public sector (net) & 80 & 126 & 105 & 93 & 81 & -40 & 17 & 23 \\
\hline Claims on central government (net) & 294 & 293 & 268 & 254 & 262 & 175 & 207 & 215 \\
\hline ECCB net credit to central government & 26 & 26 & 21 & 22 & 22 & 20 & 22 & 22 \\
\hline Commercial bank net credit to government & 268 & 266 & 247 & 232 & 240 & 154 & 185 & 193 \\
\hline Net credit to other public sector & -214 & -167 & -162 & -161 & -180 & -215 & -190 & -192 \\
\hline Credit to private sector & 1457 & 1492 & 1508 & 1601 & 1666 & 1895 & 1905 & 2022 \\
\hline Other items (net) & -320 & -414 & -300 & -153 & -906 & -942 & -946 & -946 \\
\hline Monetary liabilities (M2) & 1545 & 1871 & 2043 & 2113 & 2184 & 2365 & 2472 & 2704 \\
\hline Money (M1) & 308 & 370 & 445 & 472 & 525 & 577 & 604 & 649 \\
\hline Currency circulating outside banks & 88 & 99 & 113 & 110 & 122 & 149 & 160 & 176 \\
\hline Demand deposits & 220 & 271 & 331 & 362 & 403 & 428 & 443 & 473 \\
\hline Quasi-money & 1237 & 1502 & 1598 & 1641 & 1659 & 1788 & 1869 & 2055 \\
\hline Savings deposits & 525 & 577 & 683 & 729 & 742 & 816 & 831 & 909 \\
\hline Time deposits & 595 & 818 & 780 & 784 & 780 & 806 & 858 & 915 \\
\hline \multirow[t]{2}{*}{ Foreign currency deposits } & 117 & 107 & 135 & 128 & 137 & 166 & 180 & 231 \\
\hline & \multicolumn{8}{|c|}{ (12-month percentage change) } \\
\hline Credit to the private sector (net) & 8.0 & 2.4 & 1.1 & 4.2 & 10.4 & 18.4 & 14.4 & 6.1 \\
\hline Broad money & 6.3 & 21.1 & 9.2 & 8.3 & 6.9 & 11.9 & 13.2 & 9.4 \\
\hline Money (M1) & 0.3 & 20.0 & 20.3 & 24.9 & 18.2 & 22.3 & 14.9 & 7.4 \\
\hline \multirow[t]{2}{*}{ Quasi-money } & 7.9 & 21.4 & 6.4 & 4.3 & 3.8 & 9.0 & 12.7 & 10.0 \\
\hline & \multicolumn{8}{|c|}{ (12-month change in percent of M2 at the beginning of the period) } \\
\hline Net foreign assets & 0.6 & 21.9 & 3.3 & -0.5 & 30.0 & 41.7 & 7.0 & 4.4 \\
\hline ECCB imputed reserves & 1.5 & 4.6 & 0.9 & 1.8 & 0.9 & 1.2 & 1.2 & 1.1 \\
\hline Commercial banks' net foreign assets & -0.9 & 17.4 & 2.4 & -2.3 & 29.1 & 40.4 & 5.8 & 3.3 \\
\hline Net domestic assets & 5.7 & -0.8 & 5.9 & 8.8 & -23.1 & -29.7 & 6.2 & 5.0 \\
\hline Credit to the public sector (net) & 0.3 & 3.0 & -1.1 & 0.9 & -1.2 & -6.3 & -3.0 & 0.2 \\
\hline Claims on central government & 0.3 & -0.1 & -1.3 & 0.0 & -0.3 & -3.7 & -2.5 & 0.3 \\
\hline Credit to the rest of the public sector (net) & 0.0 & 3.1 & 0.3 & 0.9 & -0.9 & -2.5 & -0.4 & -0.1 \\
\hline Private sector & 7.5 & 2.2 & 0.9 & 3.3 & 7.7 & 13.9 & 11.0 & 4.7 \\
\hline Other items (net) & -2.1 & -6.1 & 6.1 & 4.6 & -29.7 & -37.3 & -1.8 & 0.0 \\
\hline \multicolumn{9}{|l|}{ Memorandum item: } \\
\hline Income velocity of M2 & 1.3 & 1.2 & 1.1 & $\ldots$ & 1.1 & $\ldots$ & 1.1 & 1.1 \\
\hline
\end{tabular}

Sources: Eastern Caribbean Central Bank, and Fund staff projections. 
Table 3. Antigua and Barbuda: Balance of Payments

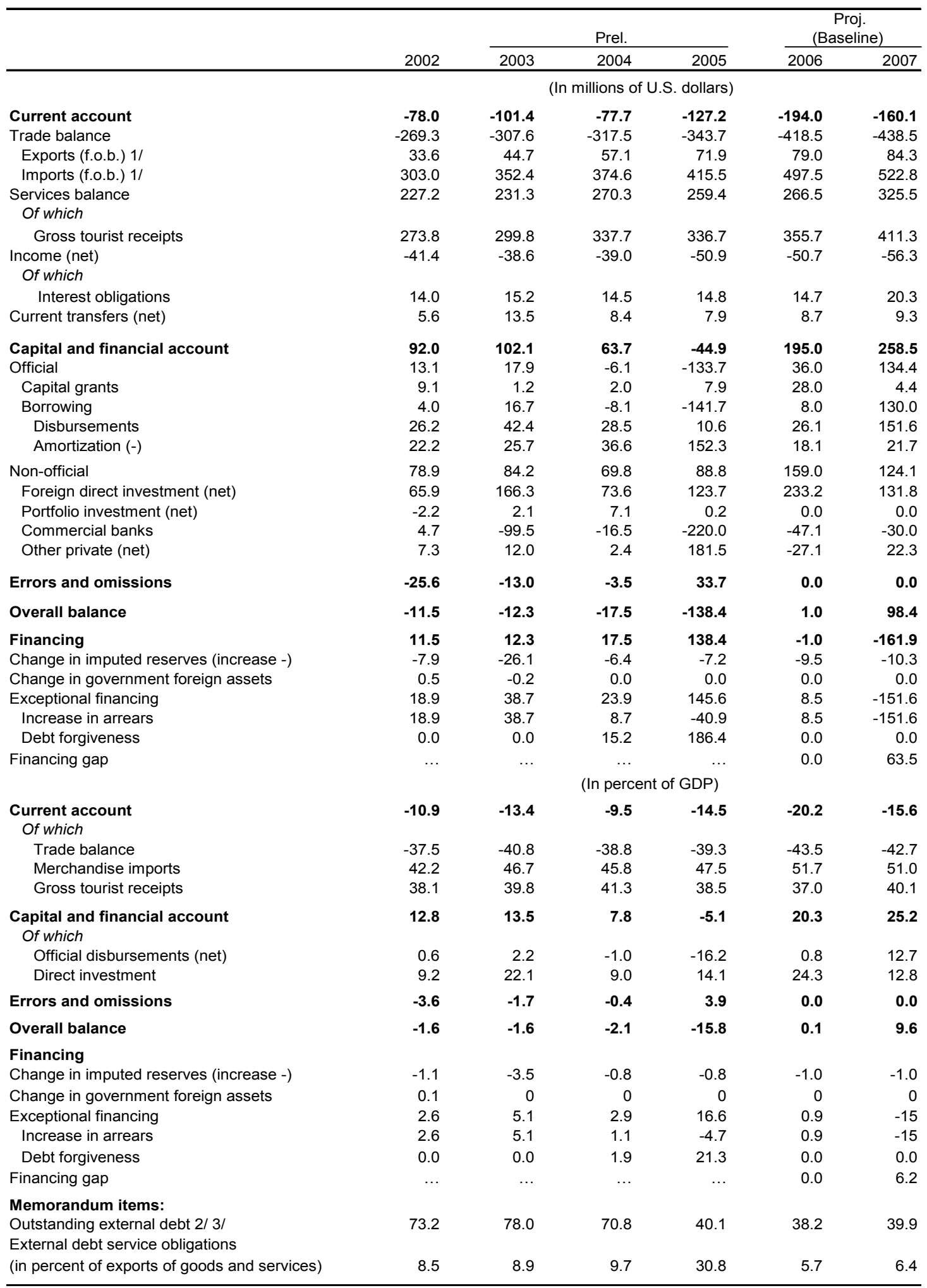

Sources: Antigua and Barbuda authorities; Eastern Caribbean Central Bank; and Fund staff estimates and projections.

1/ Based on ECCB estimates. There is a structural break in 2005 owing to introduction of data from ASYCUDA.

2/ Includes debt relief from Devcon in 2004 and Italy in 2005, and assumes the regularization of arrears in

mid-2007 through the issuance of a long-term bond carrying10 percent interest.

3/ Includes financing gap. 
Table 4. Antigua and Barbuda: Central Government Operations (In millions of Eastern Caribbean dollars)

\begin{tabular}{|c|c|c|c|c|c|c|}
\hline & \multirow[b]{2}{*}{2002} & \multirow[b]{2}{*}{2003} & \multirow[b]{2}{*}{2004} & \multirow{2}{*}{$\begin{array}{r}\text { Est. } \\
2005 \\
\end{array}$} & \multicolumn{2}{|c|}{$\begin{array}{c}\text { Proj. } \\
\text { (Baseline) }\end{array}$} \\
\hline & & & & & 2006 & 2007 \\
\hline Total revenue and grants & 421 & 430 & 477 & 515 & 678 & 649 \\
\hline $\begin{array}{l}\text { Current revenue } \\
\text { Of which }\end{array}$ & \multicolumn{4}{|c|}{ Of which } & 603 & 637 \\
\hline $\begin{array}{l}\text { Tax revenue } \\
\text { Of which } \\
\text { Tax arrear collections }\end{array}$ & 357 & 383 & 427 & 455 & 561 & 594 \\
\hline Capital grants & 25 & 3 & 5 & 21 & 76 & 12 \\
\hline Total expenditure & 658 & 625 & 612 & 683 & 833 & 757 \\
\hline Current expenditure & 558 & 544 & 557 & 589 & 665 & 635 \\
\hline Wages and salaries & 237 & 250 & 251 & 252 & 258 & 242 \\
\hline Employment contributions 1/ & 29 & 32 & 32 & 33 & 34 & 31 \\
\hline Goods and services, incl. utilities & 156 & 101 & 110 & 109 & 112 & 115 \\
\hline Interest payments 2/ & 102 & 110 & 108 & 115 & 109 & 132 \\
\hline External & 38 & 41 & 39 & 40 & 40 & 55 \\
\hline Domestic & 65 & 69 & 69 & 75 & 70 & 77 \\
\hline Pensions & 23 & 31 & 33 & 38 & 45 & 43 \\
\hline Other transfers & 11 & 20 & 23 & 42 & 108 & 72 \\
\hline \multicolumn{7}{|l|}{ Of which } \\
\hline Severances & $\ldots$ & $\ldots$ & $\ldots$ & $\ldots$ & 52 & 11 \\
\hline Capital expenditure and net lending & 100 & 81 & 55 & 94 & 168 & 123 \\
\hline Current account balance & -162 & -116 & -85 & -96 & -62 & 3 \\
\hline Primary balance & -134 & -85 & -26 & -54 & -45 & 24 \\
\hline Overall balance & -237 & -194 & -135 & -169 & -155 & -108 \\
\hline Identified Financing & 131 & 241 & 142 & 200 & 155 & -63 \\
\hline External (net) 3/ & 62 & 149 & 1 & -493 & 45 & -59 \\
\hline Increase in arrears & 51 & 104 & 23 & -110 & 23 & -409 \\
\hline Amortization & 26 & 46 & -15 & -41 & 13 & -164 \\
\hline Interest & 25 & 59 & 38 & -69 & 10 & -245 \\
\hline External borrowing & 11 & 45 & -22 & -383 & 22 & 351 \\
\hline Disbursement & 71 & 115 & 77 & 29 & 70 & 409 \\
\hline Amortization & -60 & -70 & -99 & -411 & -49 & -59 \\
\hline Domestic (net) 3/ & 69 & 92 & 100 & 189 & 110 & -5 \\
\hline Increase in arrears 4/ & 75 & 127 & 117 & 160 & 81 & -1194 \\
\hline ECCB & -8 & 0 & 0 & 0 & 0 & 0 \\
\hline Banks and others & -1 & -38 & -40 & 12 & 22 & 1189 \\
\hline Asset sales & 3 & 3 & 22 & 18 & 8 & 0 \\
\hline Debt relief 5/ & $\ldots$ & $\ldots$ & 41 & 503 & $\ldots$ & $\ldots$ \\
\hline External & $\ldots$ & $\ldots$ & 41 & 503 & $\ldots$ & $\ldots$ \\
\hline Domestic & $\ldots$ & $\cdots$ & 0 & 0 & $\cdots$ & $\cdots$ \\
\hline Statistical discrepancy & 106 & -47 & -7 & -31 & $\ldots$ & $\ldots$ \\
\hline Financing gap 6/ & $\cdots$ & $\cdots$ & $\cdots$ & $\cdots$ & $\cdots$ & 172 \\
\hline \multicolumn{7}{|l|}{ Memorandum items: } \\
\hline Public sector debt stock 7/ & 2716 & 2989 & 3035 & 2543 & 2686 & 2794 \\
\hline $\begin{array}{l}\text { Payments on the regularizing instrument } \\
\text { Of which }\end{array}$ & $\ldots$ & $\ldots$ & $\ldots$ & $\ldots$ & $\ldots$ & 48 \\
\hline Interest payments & $\ldots$ & $\ldots$ & $\ldots$ & $\ldots$ & $\ldots$ & 48 \\
\hline Interest payment on financing gap & $\ldots$ & $\ldots$ & $\ldots$ & $\ldots$ & $\ldots$ & 17 \\
\hline GDP market prices & 1938 & 2036 & 2210 & 2362 & 2597 & 2770 \\
\hline
\end{tabular}

Sources: Antigua and Barbuda authorities; and Fund staff estimates and projections.

$1 /$ Includes contributions to social security, medical benefits, and education.

2/ The projections include 10 percent interest payment on new borrowing to regularize outstanding arrears and fill financing gap.

3/ The figures for 2007 reflect the regularization of outstanding arrears.

4/ Includes interest and amortization arrears, unpaid vouchers to domestic creditors, personnel payables, and unpaid contributions.

5/ This is the debt relief from a commercial supplier in 2004, and from the Italian government in 2005.

6/ The gap is assumed to be filled through the issuing of long-term bonds with a 10 percent coupon rate.

7/ Excludes asset sales. 
Table 5. Antigua and Barbuda: Central Government Operations (In percent of GDP)

\begin{tabular}{|c|c|c|c|c|c|c|}
\hline & \multirow[b]{2}{*}{2002} & \multirow[b]{2}{*}{2003} & \multirow[b]{2}{*}{2004} & \multirow{2}{*}{$\begin{array}{r}\text { Est. } \\
2005 \\
\end{array}$} & \multicolumn{2}{|c|}{$\begin{array}{c}\text { Proj. } \\
\text { (Baseline) }\end{array}$} \\
\hline & & & & & 2006 & 2007 \\
\hline Total revenue and grants & 21.7 & 21.1 & 21.6 & 21.8 & 26.1 & 23.4 \\
\hline $\begin{array}{l}\text { Current revenue } \\
\text { Of which }\end{array}$ & 20.5 & 21.0 & 21.4 & 20.9 & 23.2 & 23.0 \\
\hline $\begin{array}{l}\text { Tax revenue } \\
\text { Of which } \\
\text { Tax arrear collections }\end{array}$ & 18.4 & 18.8 & 19.3 & 19.3 & 21.6 & 21.4 \\
\hline Capital grants & 1.3 & 0.2 & 0.2 & 0.9 & 2.9 & 0.4 \\
\hline Total expenditure and net lending & 33.9 & 30.7 & 27.7 & 28.9 & 32.1 & 27.3 \\
\hline Current expenditure & 28.8 & 26.7 & 25.2 & 24.9 & 25.6 & 22.9 \\
\hline Wages and salaries & 12.2 & 12.3 & 11.4 & 10.7 & 9.9 & 8.7 \\
\hline Employment contributions 1/ & 1.5 & 1.6 & 1.4 & 1.4 & 1.3 & 1.1 \\
\hline Goods and services, incl. utilities & 8.1 & 4.9 & 5.0 & 4.6 & 4.3 & 4.2 \\
\hline Interest payments 2/ & 5.3 & 5.4 & 4.9 & 4.9 & 4.2 & 4.7 \\
\hline External & 2.0 & 2.0 & 1.8 & 1.7 & 1.5 & 2.0 \\
\hline Domestic & 3.3 & 3.4 & 3.1 & 3.2 & 2.7 & 2.8 \\
\hline Pensions & 1.2 & 1.5 & 1.5 & 1.6 & 1.7 & 1.6 \\
\hline Other transfers & 0.6 & 1.0 & 1.1 & 1.8 & 4.2 & 2.6 \\
\hline \multicolumn{7}{|l|}{ Of which } \\
\hline Severances & $\ldots$ & $\ldots$ & $\ldots$ & $\ldots$ & 2.0 & 0.4 \\
\hline Capital expenditure and net lending & 5.1 & 4.0 & 2.5 & 4.0 & 6.5 & 4.4 \\
\hline Current account balance & -8.3 & -5.7 & -3.8 & -4.1 & -2.4 & 0.1 \\
\hline Primary balance & -6.9 & -4.2 & -1.2 & -2.3 & -1.7 & 0.8 \\
\hline Overall balance & -12.2 & -9.5 & -6.1 & -7.1 & -6.0 & -3.9 \\
\hline Identified Financing & 6.8 & 11.9 & 6.4 & 8.5 & 6.0 & -2.3 \\
\hline External (net) 3/ & 3.2 & 7.3 & 0.1 & -20.9 & 1.7 & -2.1 \\
\hline Increase in arrears & 2.6 & 5.1 & 1.1 & -4.7 & 0.9 & -14.8 \\
\hline Amortization & 1.3 & 2.3 & -0.7 & -1.7 & 0.5 & -5.9 \\
\hline Interest & 1.3 & 2.9 & 1.7 & -2.9 & 0.4 & -8.9 \\
\hline External borrowing (net) & 0.6 & 2.2 & -1.0 & -16.2 & 0.8 & 12.7 \\
\hline Disbursement & 3.6 & 5.6 & 3.5 & 1.2 & 2.7 & 14.8 \\
\hline Amortization & -3.1 & -3.4 & -4.5 & -17.4 & -1.9 & -2.1 \\
\hline Increase in foreign assets & 0.0 & 0.0 & 0.0 & 0.0 & 0.0 & 0.0 \\
\hline Domestic (net) 3/ & 3.5 & 4.5 & 4.5 & 8.0 & 4.2 & -0.2 \\
\hline Increase in arrears 4/ & 3.9 & 6.2 & 5.3 & 6.8 & 3.1 & -43.1 \\
\hline ECCB (net) & -0.4 & 0.0 & 0.0 & 0.0 & 0.0 & 0.0 \\
\hline Banks and others (net) & -0.1 & -1.8 & -1.8 & 0.5 & 0.8 & 42.9 \\
\hline Asset sales & 0.2 & 0.1 & 1.0 & 0.8 & 0.3 & 0.0 \\
\hline Debt relief $5 /$ & $\ldots$ & $\ldots$ & 1.9 & 21.3 & $\ldots$ & $\ldots$ \\
\hline External & $\ldots$ & $\ldots$ & 1.9 & 21.3 & $\ldots$ & $\ldots$ \\
\hline Domestic & $\ldots$ & $\ldots$ & 0.0 & 0.0 & $\ldots$ & $\ldots$ \\
\hline Statistical discrepancy & 5.5 & -2.3 & -0.3 & -1.3 & $\ldots$ & $\ldots$ \\
\hline Financing gap 6/ & $\ldots$ & $\cdots$ & $\ldots$ & $\ldots$ & $\ldots$ & 6.2 \\
\hline \multicolumn{7}{|l|}{ Memorandum item: } \\
\hline Public sector debt stock $7 /$ & 140.1 & 146.8 & 137.4 & 107.7 & 103.5 & 100.9 \\
\hline $\begin{array}{l}\text { Payments on the regularizing instrument } \\
\text { Of which }\end{array}$ & $\ldots$ & $\ldots$ & $\ldots$ & $\ldots$ & $\cdots$ & 1.7 \\
\hline Interest payments & $\ldots$ & $\ldots$ & $\ldots$ & $\ldots$ & $\ldots$ & 1.7 \\
\hline Interest payment on financing gap & $\ldots$ & $\ldots$ & $\ldots$ & $\ldots$ & $\ldots$ & 0.6 \\
\hline GDP market prices (millions of EC $\$$ ) & 1938 & 2036 & 2210 & 2362 & 2597 & 2770 \\
\hline
\end{tabular}

Sources: Antigua and Barbuda authorities; and Fund staff estimates and projections.

$1 /$ Includes contributions to social security, medical benefits, and education.

2/ The projections include 10 percent interest payment on new borrowing to regularize outstanding arrears and fill financing gap. 3/ The figures for 2007 reflect the regularization of outstanding arrears.

$4 /$ Includes interest and amortization arrears, unpaid vouchers to domestic creditors, personnel payables, and unpaid contributions.

$5 /$ This is the debt relief from a commercial supplier in 2004, and from the Italian government in 2005.

$6 /$ The gap is assumed to be filled through the issuing of long-term bonds with a 10 percent coupon rate.

7/ Excludes asset sales. 
Table 6. Antigua and Barbuda: Structure of Government Debt, June 2006

(In millions of USD, unless noted otherwise)

\begin{tabular}{|c|c|c|c|c|c|c|c|c|c|}
\hline & \multicolumn{5}{|c|}{ Structure of Debt Stock } & \multicolumn{4}{|c|}{ Structure of Arrears } \\
\hline & \multirow{2}{*}{$\begin{array}{l}\text { End- } \\
2005\end{array}$} & \multirow{2}{*}{$\begin{array}{l}\text { June } \\
2006\end{array}$} & \multirow{2}{*}{$\begin{array}{l}\text { Percentage } \\
\text { Earmarked }\end{array}$} & \multicolumn{2}{|c|}{ Percent of } & \multirow[b]{2}{*}{ Principal } & \multirow[b]{2}{*}{ Interest } & \multirow[b]{2}{*}{ Total } & \multirow{2}{*}{$\begin{array}{l}\text { Percent } \\
\text { of GDP }\end{array}$} \\
\hline & & & & Total Debt & GDP & & & & \\
\hline Total government debt $1 /$ & 941.9 & 982.5 & 23.0 & 100.0 & 102.2 & 364.9 & 221.7 & 586.6 & 61.0 \\
\hline Total external debt & 351.0 & 359.8 & 44.9 & 36.6 & 37.4 & 65.2 & 95.5 & 160.7 & 16.7 \\
\hline Central government & 324.4 & 332.8 & 45.8 & 33.9 & 34.6 & 53.6 & 87.5 & 141.1 & 14.7 \\
\hline Multilateral & 8.8 & 9.3 & 0.0 & 0.9 & 1.0 & 2.9 & 1.5 & 4.4 & 0.5 \\
\hline CDB & 0.9 & 0.9 & 0.0 & 0.1 & 0.1 & 0.0 & 0.0 & 0.0 & 0.0 \\
\hline EEC/EIB & 6.4 & 6.8 & 0.0 & 0.7 & 0.7 & 2.2 & 0.6 & 2.8 & 0.3 \\
\hline OPEC & 1.5 & 1.5 & 0.0 & 0.2 & 0.2 & 0.7 & 0.9 & 1.5 & 0.2 \\
\hline Bilateral & 90.1 & 92.1 & 0.0 & 9.4 & 9.6 & 24.5 & 18.6 & 43.1 & 4.5 \\
\hline Paris Club & 58.1 & 59.8 & 0.0 & 6.1 & 6.2 & 14.6 & 17.4 & 32.0 & 3.3 \\
\hline Germany & 3.8 & 3.9 & 0.0 & 0.4 & 0.4 & 1.0 & 0.2 & 1.2 & 0.1 \\
\hline France & 26.7 & 27.1 & 0.0 & 2.8 & 2.8 & 9.4 & 5.0 & 14.4 & 1.5 \\
\hline U.S. & 22.2 & 23.3 & 0.0 & 2.4 & 2.4 & 2.3 & 12.2 & 14.5 & 1.5 \\
\hline U.K. & 5.4 & 5.5 & 0.0 & 0.6 & 0.6 & 1.9 & 0.0 & 1.9 & 0.2 \\
\hline Other & 32.0 & 32.4 & 0.0 & 3.3 & 3.4 & 9.9 & 1.2 & 11.1 & 1.2 \\
\hline China & 15.8 & 15.9 & 0.0 & 1.6 & 1.7 & 6.2 & 0.0 & 6.3 & 0.7 \\
\hline Kuwait & 14.0 & 14.4 & 0.0 & 1.5 & 1.5 & 3.7 & 1.2 & 4.8 & 0.5 \\
\hline Trinidad & 2.1 & 2.1 & 0.0 & 0.2 & 0.2 & 0.0 & 0.0 & 0.0 & 0.0 \\
\hline Commercial & 225.5 & 231.4 & 65.8 & 23.6 & 24.1 & 26.2 & 67.4 & 93.6 & 9.7 \\
\hline \multicolumn{10}{|l|}{ Of which } \\
\hline IHI Debt Settlement Company 2/ & 43.1 & 42.9 & 100.0 & 4.4 & 4.5 & 6.1 & 0.0 & 6.1 & 0.6 \\
\hline Stanford Financial Group Limited & 58.7 & 58.7 & 100.0 & 6.0 & 6.1 & 10.0 & 0.1 & 10.2 & 1.1 \\
\hline Banco do Brasil 3/ & 60.5 & 63.8 & 0.0 & 6.5 & 6.6 & 0.0 & 0.0 & 0.0 & 0.0 \\
\hline $\begin{array}{l}\text { Republic Finance and } \\
\text { Merchant Bank Ltd. }\end{array}$ & 27.9 & 30.4 & 100.0 & 3.1 & 3.2 & 0.0 & 4.6 & 4.6 & 0.5 \\
\hline Others & 35.3 & 35.7 & 57.3 & 3.6 & 3.7 & 10.0 & 62.6 & 72.6 & 7.6 \\
\hline Government guaranteed debt & 26.6 & 27.0 & 33.9 & 2.7 & 2.8 & 11.7 & 8.0 & 19.7 & 2.0 \\
\hline Total Domestic Public Debt & 590.9 & 622.7 & 10.3 & 63.4 & 64.8 & 299.7 & 126.2 & 425.9 & 44.3 \\
\hline Central government & 569.9 & 599.5 & 9.8 & 61.0 & 62.3 & 295.2 & 125.9 & 421.1 & 43.8 \\
\hline Bank loans and overdrafts & 129.5 & 120.2 & 48.7 & 12.2 & 12.5 & 4.8 & 1.9 & 6.7 & 0.7 \\
\hline Unpaid contributions 4/ & 245.7 & 256.4 & 0.0 & 26.1 & 26.7 & 169.1 & 87.2 & 256.4 & 26.7 \\
\hline Government securities & 85.1 & 105.4 & 0.0 & 10.7 & 11.0 & 3.7 & 36.8 & 40.5 & 4.2 \\
\hline Supplier credits $5 /$ & 47.7 & 53.0 & 0.0 & 5.4 & 5.5 & 53.0 & 0.0 & 53.0 & 5.5 \\
\hline Wage packpay and other arrears & 61.9 & 64.5 & 0.0 & 6.6 & 6.7 & 64.5 & 0.0 & 64.5 & 6.7 \\
\hline Government guaranteed debt & 21.0 & 23.2 & 23.5 & 2.4 & 2.4 & 4.5 & 0.3 & 4.9 & 0.5 \\
\hline
\end{tabular}

Sources: Antigua and Barbuda authorities, HLHZ and Fund staff estimates.

$1 /$ Includes both principal and interest arrears.

$2 /$ This loan is currently under investigation.

$3 /$ Status to be verified. In view of the authorities this is not a legitimate claim as the funds were never disbursed to Antigua.

4/ Assuming that the stock of arrears to the Social Security scheme accrued 10 percent interest.

5/ Includes vouchers for capital as well as for goods and services. Capital vouchers shown as of December 2005. 
Table 7. Antigua and Barbuda: Public Sector Debt Sustainability Framework, 2001-11

(In percent of GDP, unless otherwise indicated)

\begin{tabular}{|c|c|c|c|c|c|c|c|c|c|c|c|c|}
\hline & \multicolumn{5}{|c|}{ Actual } & \multicolumn{6}{|c|}{ Projections } & \multirow{2}{*}{$\begin{array}{c}\text { Debt-stabilizing } \\
\text { primary } \\
\text { balance 10/ }\end{array}$} \\
\hline & 2001 & 2002 & 2003 & 2004 & 2005 & 2006 & 2007 & 2008 & 2009 & 2010 & 2011 & \\
\hline $\begin{array}{l}\text { Baseline: Public sector debt } 1 / \\
\text { Of which }\end{array}$ & 129.4 & 140.1 & 146.8 & 137.4 & 107.7 & 103.5 & 100.9 & 101.8 & 97.8 & 94.4 & 90.6 & 0.18 \\
\hline Foreign-currency denominated & 66.6 & 73.2 & 78.0 & 70.8 & 40.1 & 38.2 & 39.9 & 43.6 & 43.7 & 44.0 & 43.7 & \\
\hline Change in public sector debt & 5.1 & 10.8 & 6.7 & -9.5 & -29.7 & -4.2 & -2.6 & 0.9 & -3.9 & -3.5 & -3.7 & \\
\hline Identified debt-creating flows $(4+7+12)$ & 8.7 & 7.0 & -2.0 & -10.0 & -19.8 & -3.8 & -2.6 & 0.9 & -2.6 & -3.4 & -3.8 & \\
\hline Primary deficit & 6.8 & 6.9 & 4.2 & 1.2 & 2.3 & 1.7 & -0.8 & -1.2 & -2.3 & -3.4 & -4.0 & \\
\hline Revenue and grants & 19.2 & 21.7 & 21.1 & 21.6 & 21.8 & 26.1 & 23.4 & 23.3 & 23.8 & 24.4 & 24.6 & \\
\hline Primary (noninterest) expenditure & 26.0 & 28.7 & 25.3 & 22.8 & 24.1 & 27.9 & 22.6 & 22.0 & 21.4 & 21.0 & 20.7 & \\
\hline Automatic debt dynamics $2 /$ & 2.0 & 0.1 & -6.1 & -9.4 & -0.7 & -5.5 & -1.7 & 2.1 & -0.3 & 0.0 & 0.2 & \\
\hline $\begin{array}{l}\text { Contribution from interest rate/growth differential 3/ } \\
\text { Of which }\end{array}$ & 2.0 & 0.1 & -6.1 & -9.4 & -0.7 & -5.5 & -1.7 & 2.1 & -0.3 & 0.0 & 0.2 & \\
\hline Contribution from real interest rate & 3.8 & 2.6 & -0.6 & -2.5 & 6.3 & 2.4 & 2.0 & 3.9 & 4.0 & 4.1 & 4.1 & \\
\hline Contribution from real GDP growth & -1.9 & -2.5 & -5.6 & -6.9 & -7.0 & -7.9 & -3.7 & -1.7 & -4.2 & -4.1 & -3.9 & \\
\hline Contribution from exchange rate depreciation $4 /$ & 0.0 & 0.0 & 0.0 & 0.0 & 0.0 & $\ldots$ & $\ldots$ & $\ldots$ & $\ldots$ & $\ldots$ & $\ldots$ & \\
\hline Denominator $=1+g+p+g p$ & 1.0 & 1.0 & 1.1 & 1.1 & 1.0 & 1.1 & 1.1 & 1.0 & 1.1 & 1.1 & 1.1 & \\
\hline Other identified debt-creating flows & 0.0 & 0.0 & 0.0 & -1.9 & -21.3 & 0.0 & 0.0 & 0.0 & 0.0 & 0.0 & 0.0 & \\
\hline Privatization receipts (negative) & 0.0 & 0.0 & 0.0 & 0.0 & 0.0 & 0.0 & 0.0 & 0.0 & 0.0 & 0.0 & 0.0 & \\
\hline Recognition of implicit or contingent liabilities & 0.0 & 0.0 & 0.0 & 0.0 & 0.0 & 0.0 & 0.0 & 0.0 & 0.0 & 0.0 & 0.0 & \\
\hline Other (debt relief in 2004-05) & 0.0 & 0.0 & 0.0 & -1.9 & -21.3 & 0.0 & 0.0 & 0.0 & 0.0 & 0.0 & 0.0 & \\
\hline Residual, including asset changes (2-3) 5 / & -3.7 & 3.8 & 8.7 & 0.6 & -9.9 & -0.4 & 0.0 & 0.0 & -1.3 & 0.0 & 0.0 & \\
\hline Public sector debt-to-revenue ratio $1 /$ & 673.4 & 645.1 & 694.7 & 635.7 & 493.9 & 396.1 & 430.3 & 437.5 & 411.8 & 387.2 & 367.9 & \\
\hline Gross financing need $6 /$ & 43.4 & 45.5 & 43.8 & 39.8 & 52.2 & 35.1 & 20.1 & 14.5 & 11.9 & 9.5 & 7.6 & \\
\hline in billions of U.S. dollars & 0.3 & 0.3 & 0.3 & 0.3 & 0.5 & 0.3 & 0.2 & 0.2 & 0.1 & 0.1 & 0.1 & \\
\hline \multicolumn{13}{|l|}{ Alternative Scenarios } \\
\hline A1. Scenario with key variables at their historical averages $7 /$ & & & & & & 103.5 & 101.7 & 100.0 & 97.1 & 95.5 & 94.1 & -3.5 \\
\hline $\begin{array}{l}\text { A2. Scenario with no policy change (constant primary balance) } \\
\text { in } 2006-2011\end{array}$ & & & & & & 103.5 & 103.5 & 107.4 & 107.5 & 109.2 & 111.2 & 0.2 \\
\hline A3. A natural disaster scenario (a hurricane in 2007) 8/ & & & & & & 103.5 & 104.4 & 104.7 & 103.8 & 105.2 & 107.6 & 0.4 \\
\hline \multicolumn{13}{|l|}{ Key Macroeconomic and Fiscal Assumptions Underlying Baseline } \\
\hline Real GDP growth (in percent) & 1.5 & 2.0 & 4.3 & 5.2 & 5.3 & 8.0 & 3.8 & 1.8 & 4.5 & 4.5 & 4.5 & \\
\hline Average nominal interest rate on public debt (in percent) $9 /$ & 4.7 & 4.1 & 4.0 & 3.6 & 3.8 & 4.3 & 4.9 & 6.8 & 7.1 & 7.3 & 7.4 & \\
\hline Average nominal interest rate on forex debt (in percent) 6 / & 3.1 & 3.0 & 2.9 & 2.5 & 2.6 & 4.2 & 5.5 & 8.0 & 8.4 & 8.7 & 9.0 & \\
\hline Average real interest rate (nominal rate minus change in GDP deflator, & 3.2 & 2.1 & -0.3 & -1.6 & 4.7 & 2.6 & 2.1 & 4.0 & 4.3 & 4.6 & 4.8 & \\
\hline Exchange rate (LC per US dollar) & 2.7 & 2.7 & 2.7 & 2.7 & 2.7 & 2.7 & 2.7 & 2.7 & 2.7 & 2.7 & 2.7 & \\
\hline Nominal depreciation of local currency (LC per dollar) & 0.0 & 0.0 & 0.0 & 0.0 & 0.0 & 0.0 & 0.0 & 0.0 & 0.0 & 0.0 & 0.0 & \\
\hline $\begin{array}{l}\text { Exchange rate (US dollar per LC) } \\
\text { in percent) }\end{array}$ & 0.4 & 0.4 & 0.4 & 0.4 & 0.4 & 0.4 & 0.4 & 0.4 & 0.4 & 0.4 & 0.4 & \\
\hline $\begin{array}{l}\text { Nominal appreciation (increase in US dollar value of local currency, } \\
\text { in percent) }\end{array}$ & 0.0 & 0.0 & 0.0 & 0.0 & 0.0 & $\ldots$ & $\ldots$ & $\ldots$ & $\ldots$ & $\ldots$ & $\ldots$ & \\
\hline Inflation rate (GDP deflator, in percent) & 1.5 & 2.0 & 4.3 & 5.2 & -0.9 & 1.8 & 2.8 & 2.8 & 2.8 & 2.7 & 2.6 & \\
\hline Growth of real primary spending (deflated by GDP deflator, in percent) & 22.9 & 9.3 & -11.1 & -7.0 & 13.9 & 25.1 & -15.8 & -0.7 & 1.6 & 2.3 & 2.9 & \\
\hline Primary deficit & 6.8 & 6.9 & 4.2 & 1.2 & 2.3 & 1.7 & -0.8 & -1.2 & -2.3 & -3.4 & -4.0 & \\
\hline \multicolumn{13}{|l|}{ B. Bound Tests } \\
\hline B1. Real interest rate is at baseline plus one-half standard deviation & & & & & & 103.5 & 102.1 & 104.2 & 101.5 & 99.2 & 96.6 & 1.3 \\
\hline B2. Real GDP growth is at baseline minus one-half standard deviation & & & & & & 103.5 & 101.8 & 103.8 & 101.1 & 99.0 & 96.8 & 0.9 \\
\hline B3. Primary balance is at baseline minus one-half standard deviation & & & & & & 103.5 & 102.3 & 104.7 & 102.3 & 100.3 & 98.0 & 0.2 \\
\hline B4. Combination of B1-B3 using 1/4 standard deviation shocks & & & & & & 103.5 & 102.6 & 105.3 & 103.0 & 101.3 & 99.3 & 1.1 \\
\hline B5. One time 30 percent real depreciation in 2006 10/ & & & & & & 103.5 & 119.3 & 120.5 & 116.6 & 113.1 & 109.4 & 0.2 \\
\hline B6. 10 percent of GDP increase in other debt-creating flows in 2006 & & & & & & 103.5 & 110.9 & 112.0 & 108.0 & 104.6 & 100.8 & 0.2 \\
\hline
\end{tabular}

$1 /$ Includes gross central government and government guaranteed debt.

2/ Derived as $[(r-p(1+g)-g+a e(1+r)] /(1+g+p+g p)]$ times previous period debt ratio, with $r=$ interest rate; $p=$ growth rate of GDP deflator; $g=$ real GDP growth rate;

$a=$ share of foreign-currency denominated debt; and $e=$ nominal exchange rate depreciation (measured by increase in local currency value of $U . S$. dollar).

$3 /$ The real interest rate contribution is derived from the denominator in footnote $2 /$ as $r-\pi(1+g)$ and the real growth contribution as -g.

$4 /$ The exchange rate contribution is derived from the numerator in footnote $2 /$ as ae $(1+r)$.

$5 /$ For projections, this line includes exchange rate changes.

6/ Defined as public sector deficit, plus amortization of medium and long-term public sector debt, plus short-term debt at end of previous period.

7/ The key variables include real GDP growth; real interest rate; and primary balance in percent of GDP.

8/ Dynamics of GDP growth and the primary balance are taken from the average impact of 12 large natural disasters in the ECCU (Rasmussen, WP/04/224).

9/ Derived as nominal interest expenditure divided by previous period debt stock.

10/ Assumes that key variables (real GDP growth, real interest rate, and other identified debt-creating flows) remain at the level of the last projection year. 
Table 8. Antigua and Barbuda: External Debt Sustainability Framework, 2001-11

(In percent of GDP, unless otherwise indicated)

\begin{tabular}{|c|c|c|c|c|c|c|c|c|c|c|c|c|}
\hline & \multicolumn{5}{|c|}{ Actual } & \multicolumn{6}{|c|}{ Projections } & \multirow{2}{*}{$\begin{array}{c}\text { Debt-stabilizing } \\
\text { non-interest } \\
\text { current account } 7 /\end{array}$} \\
\hline & 2001 & 2002 & 2003 & 2004 & 2005 & 2006 & 2007 & 2008 & 2009 & 2010 & 2011 & \\
\hline Baseline: External debt & 66.6 & 73.2 & 78.0 & 70.8 & 40.1 & 38.2 & 39.9 & 43.6 & 43.7 & 44.0 & 43.7 & -11.2 \\
\hline Change in external debt & 0.4 & 6.7 & 4.7 & -7.2 & -30.6 & -1.9 & 1.7 & 3.7 & 0.2 & 0.3 & -0.3 & \\
\hline Identified external debt-creating flows $(4+8+9)$ & -7.8 & -1.0 & -14.6 & -7.0 & -2.5 & -7.0 & 1.4 & 3.2 & 0.9 & -0.4 & -1.7 & \\
\hline Current account deficit, excluding interest payments & 6.0 & 8.9 & 11.4 & 7.7 & 12.8 & 18.7 & 13.6 & 12.5 & 11.0 & 9.7 & 8.4 & \\
\hline Deficit in balance of goods and services & 5.8 & 5.9 & 10.1 & 5.8 & 9.6 & 15.8 & 11.0 & 10.0 & 8.8 & 7.7 & 6.6 & \\
\hline Exports & 62.7 & 59.6 & 60.7 & 64.1 & 62.0 & 60.1 & 64.1 & 63.2 & 64.0 & 64.8 & 65.6 & \\
\hline Imports & 68.5 & 65.5 & 70.9 & 69.9 & 71.6 & 75.9 & 75.1 & 73.2 & 72.8 & 72.4 & 72.2 & \\
\hline Net non-debt creating capital inflows (negative) & -13.9 & -9.2 & -22.1 & -9.0 & -14.1 & -24.3 & -12.8 & -11.6 & -11.7 & -11.8 & -11.9 & \\
\hline Automatic debt dynamics $1 /$ & 0.0 & -0.7 & -4.0 & -5.8 & -1.2 & -1.4 & 0.6 & 2.3 & 1.6 & 1.7 & 1.9 & \\
\hline Denominator: $1+g+r+g r$ & 1.0 & 1.0 & 1.1 & 1.1 & 1.0 & 1.1 & 1.1 & 1.0 & 1.1 & 1.1 & 1.1 & \\
\hline Contribution from nominal interest rate & 2.0 & 1.9 & 1.9 & 1.7 & 1.7 & 1.5 & 2.0 & 3.0 & 3.4 & 3.6 & 3.7 & \\
\hline Contribution from real GDP growth & -1.0 & -1.3 & -2.9 & -3.7 & -3.6 & -2.9 & -1.4 & -0.7 & -1.8 & -1.8 & -1.8 & \\
\hline Contribution from price and exchange rate changes $2 /$ & -1.0 & -1.3 & -3.0 & -3.9 & 0.7 & $\ldots$ & $\ldots$ & $\ldots$ & $\ldots$ & $\ldots$ & $\ldots$ & \\
\hline Residual, incl. change in gross foreign assets (2-3) 3 / & 8.2 & 7.6 & 19.3 & -0.2 & -28.1 & 5.1 & 0.3 & 0.4 & -0.8 & 0.7 & 1.4 & \\
\hline External debt-to-exports ratio (in percent) & 106.2 & 122.9 & 128.4 & 110.4 & 64.7 & 63.6 & 62.3 & 68.9 & 68.3 & 67.9 & 66.6 & \\
\hline Gross external financing need (in billions of US dollars) 4 / & 0.1 & 0.1 & 0.1 & 0.1 & 0.3 & 0.2 & 0.2 & 0.2 & 0.2 & 0.2 & 0.2 & \\
\hline in percent of GDP & 11.3 & 13.9 & 16.9 & 14.0 & 31.9 & 22.1 & 17.7 & 17.6 & 16.3 & 14.8 & 13.5 & \\
\hline \multicolumn{13}{|l|}{ Alternative Scenarios } \\
\hline A1. Scenario with key variables at their historical averages $5 /$ & & & & & & 38.2 & 36.8 & 35.5 & 33.3 & 32.5 & 32.4 & -11.1 \\
\hline A2. A natural disaster scenario (a hurricane in 2007) /6 & & & & & & 38.2 & 38.0 & 41.1 & 45.0 & 46.6 & 46.5 & -11.1 \\
\hline \multicolumn{13}{|l|}{ Key Macroeconomic Assumptions Underlying Baseline } \\
\hline Real GDP growth (in percent) & 1.5 & 2.0 & 4.3 & 5.2 & 5.3 & 8.0 & 3.8 & 1.8 & 4.5 & 4.5 & 4.5 & \\
\hline $\begin{array}{l}\text { Exchange rate appreciation (US dollar value of local currency, } \\
\text { change in percent) }\end{array}$ & 0.0 & 0.0 & 0.0 & 0.0 & 0.0 & 0.0 & 0.0 & 0.0 & 0.0 & 0.0 & 0.0 & \\
\hline GDP deflator (change in domestic currency) & 1.5 & 2.0 & 4.3 & 5.2 & -0.9 & 1.8 & 2.8 & 2.8 & 2.8 & 2.7 & 2.6 & \\
\hline GDP deflator in US dollars (change in percent) & 1.5 & 2.0 & 4.3 & 5.2 & -0.9 & 1.8 & 2.8 & 2.8 & 2.8 & 2.7 & 2.6 & \\
\hline Nominal external interest rate (in percent) & 3.1 & 3.0 & 2.9 & 2.5 & 2.6 & 4.2 & 5.5 & 8.0 & 8.4 & 8.7 & 9.0 & \\
\hline Growth of exports (US dollar terms, in percent) & -4.4 & -3.9 & 7.1 & 14.5 & 3.4 & 6.5 & 13.8 & 3.2 & 8.7 & 8.6 & 8.6 & \\
\hline Growth of imports (US dollar terms, in percent) & 7.5 & -3.4 & 13.7 & 7.0 & 9.6 & 16.4 & 5.6 & 2.1 & 6.7 & 6.8 & 6.8 & \\
\hline Current account balance, excluding interest payments & -6.0 & -8.9 & -11.4 & -7.7 & -12.8 & -18.7 & -13.6 & -12.5 & -11.0 & -9.7 & -8.4 & \\
\hline Net non-debt creating capital inflows & 13.9 & 9.2 & 22.1 & 9.0 & 14.1 & 24.3 & 12.8 & 11.6 & 11.7 & 11.8 & 11.9 & \\
\hline \multicolumn{13}{|l|}{ B. Bound Tests } \\
\hline \multicolumn{6}{|c|}{ B1. Nominal interest rate is at historical average plus one half of standard deviation } & 38.2 & 40.1 & 43.9 & 44.3 & 44.8 & 44.7 & -11.0 \\
\hline \multicolumn{6}{|c|}{ B2. Real GDP growth is at historical average minus one half of standard deviation } & 38.2 & 40.1 & 43.9 & 44.2 & 44.5 & 44.2 & -11.3 \\
\hline \multicolumn{6}{|c|}{ B3. Non-interest current account is at historical average minus one half of standard deviation } & 38.2 & 42.7 & 49.2 & 52.2 & 55.4 & 58.1 & -10.9 \\
\hline \multicolumn{6}{|l|}{ B4. Combination of B1-B3 using 1/4 standard deviation shocks } & 38.2 & 41.5 & 46.8 & 48.5 & 50.4 & 51.7 & -11.0 \\
\hline \multicolumn{6}{|l|}{ B5. One time 30 percent real depreciation in 2006} & 38.2 & 52.5 & 51.6 & 46.3 & 41.8 & 36.8 & -17.1 \\
\hline
\end{tabular}

1/ Derived as $[r-g-r(1+g)+e a(1+r)] /(1+g+r+g r)$ times previous period debt stock, with $r=$ nominal effective interest rate on external debt; $r=$ change in domestic GDP deflator in US dollar terms, $g=$ real GDP growth rate, $e=$ nominal appreciation (increase in dollar value of domestic currency), and a = share of domestic-currency denominated debt in total external debt.

$2 /$ The contribution from price and exchange rate changes is defined as $[-r(1+g)+e a(1+r)] /(1+g+r+g r)$ times previous period debt stock. $r$ increases with an appreciating domestic currency (e $>0$ ) and rising inflation (based on GDP deflator).

$3 /$ For projection, line includes the impact of price and exchange rate changes.

4/ Defined as current account deficit, plus amortization on medium- and long-term debt, plus short-term debt at end of previous period.

5/ The key variables include real GDP growth; nominal interest rate; dollar deflator growth; and both non-interest current account and non-debt inflows in percent of GDP.

6/ Dynamics of GDP growth and the current account are taken from the average impact of 12 large natural disasters in the ECCU (Rasmussen, WP/04/224).

7/ Long-run, constant balance that stabilizes the debt ratio assuming that key variables (real GDP growth, nominal interest rate, dollar deflator growth, and non-debt inflows in percent of GDP) remain at their levels of the last projection year. 
Figure 7. Antigua and Barbuda: External Debt Sustainability: Bound Tests 1/ (External debt in percent of GDP)
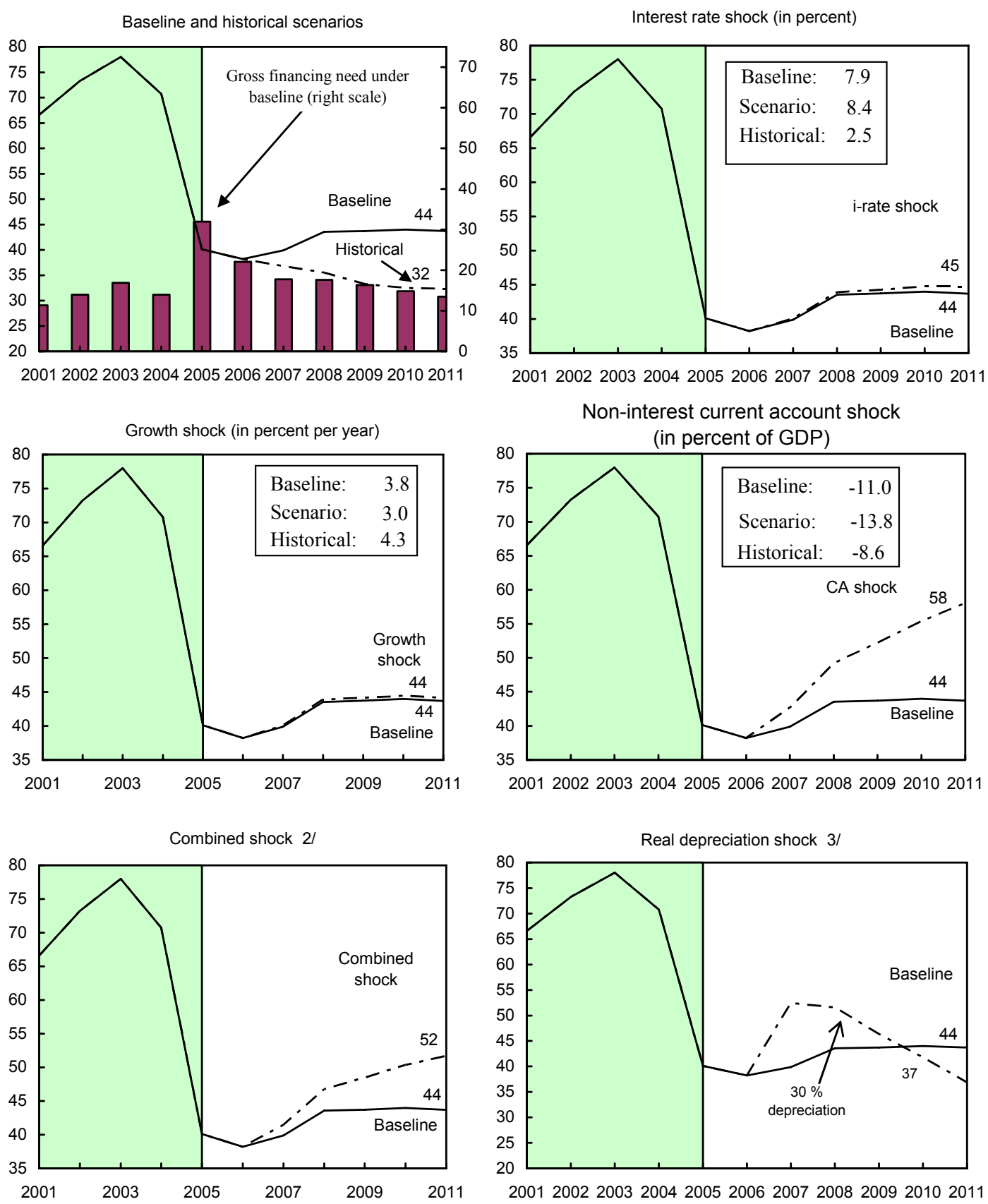

Sources: International Monetary Fund, Country desk data, and staff estimates.

1/ Shaded areas represent actual data. Individual shocks are permanent one-half standard deviation shocks. Figures in the boxes represent average projections for the respective variables in the baseline and scenario being presented. Ten-year historical average for the variable is also shown. 2/ Permanent 1/2 standard deviation shocks applied to real interest rate, growth rate, and current account balance.

3/ One-time real depreciation of 30 percent occurs in 2006. 
Table 9. Antigua and Barbuda: Accounts of Broader Public Sector 1/ (In percent of GDP)

\begin{tabular}{|c|c|c|c|c|}
\hline & 2002 & 2003 & 2004 & 2005 \\
\hline \multicolumn{5}{|l|}{ Central government } \\
\hline Total revenue and grants & 21.7 & 21.1 & 21.6 & 21.8 \\
\hline Total expenditure & 33.9 & 30.7 & 27.7 & 28.9 \\
\hline Current expenditure & 28.8 & 26.7 & 25.2 & 24.9 \\
\hline Wages and salaries & 12.2 & 12.3 & 11.4 & 10.7 \\
\hline Capital expenditure & 5.1 & 4.0 & 2.5 & 4.0 \\
\hline Primary balance & -6.9 & -4.2 & -1.2 & -2.3 \\
\hline Overall balance & -12.2 & -9.5 & -6.1 & -7.1 \\
\hline Government debt & 140.1 & 146.8 & 137.4 & 107.7 \\
\hline \multicolumn{5}{|l|}{ Statutory bodies $1 /$} \\
\hline Total revenue and grants & 19.7 & 20.1 & 19.3 & 19.5 \\
\hline Total expenditure & 14.1 & 14.7 & 13.9 & 15.0 \\
\hline Current expenditure & 11.2 & 11.5 & 11.3 & 12.6 \\
\hline Wages and salaries & 2.3 & 2.5 & 2.3 & 2.5 \\
\hline Capital expenditure & 2.0 & 2.4 & 1.7 & 1.4 \\
\hline Transfers to the government & 0.9 & 0.8 & 0.9 & 1.0 \\
\hline Primary balance & 6.2 & 5.8 & 5.7 & 4.7 \\
\hline Overall balance & 5.7 & 5.4 & 5.4 & 4.6 \\
\hline \multicolumn{5}{|l|}{ Public enterprises $1 /$} \\
\hline Total revenue and grants & 2.1 & 1.8 & 2.0 & 1.6 \\
\hline Total expenditure & 2.8 & 2.1 & 2.0 & 1.5 \\
\hline Current expenditure & 2.1 & 1.9 & 1.9 & 1.4 \\
\hline Wages and salaries & 0.3 & 0.3 & 0.3 & 0.3 \\
\hline Capital expenditure & 0.7 & 0.2 & 0.0 & 0.0 \\
\hline Primary balance & -0.5 & -0.1 & 0.2 & 0.2 \\
\hline Overall balance & -0.7 & -0.3 & 0.0 & 0.1 \\
\hline \multicolumn{5}{|l|}{ Broader public sector $1 / 2 /$} \\
\hline Total revenue and grants & 42.7 & 42.2 & 42.0 & 41.9 \\
\hline Total expenditure & 48.4 & 45.0 & 41.2 & 43.0 \\
\hline Current expenditure & 40.6 & 38.5 & 36.9 & 37.6 \\
\hline Wages and salaries & 14.8 & 15.0 & 13.9 & 13.4 \\
\hline Capital expenditure & 7.8 & 6.6 & 4.2 & 5.4 \\
\hline Primary balance & 0.2 & 3.1 & 6.1 & 4.1 \\
\hline Overall balance & -5.7 & -2.8 & 0.8 & -1.1 \\
\hline Net public debt 3/ & 112.4 & 116.3 & 107.6 & 77.5 \\
\hline
\end{tabular}

Sources: Antigua and Barbuda authorities; and Fund Staff estimates

1/ Broader public sector is defined as the central government and four statutory bodies: the social security scheme, the medical benefits system, the education board and the APUA; and three public enterprises: the state insurance company, the central planning and housing authority, and the national solid waste management company.

2/ Nets out intra-public sector transfers.

$3 /$ Nets out intra-public sector debt. 
Table 10. Antigua and Barbuda: Selected Indicators of Vulnerability

\begin{tabular}{|c|c|c|c|c|c|}
\hline & 2001 & 2002 & 2003 & 2004 & $\begin{array}{l}\text { Prel. } \\
2005 \\
\end{array}$ \\
\hline \multicolumn{6}{|l|}{ Financial indicators } \\
\hline Broad money (12-month percent change) & 4.8 & 6.3 & 21.1 & 9.2 & 6.9 \\
\hline Private sector credit (12-month percent change) & 3.1 & 8.0 & 2.4 & 1.1 & 10.4 \\
\hline \multicolumn{6}{|l|}{ Commercial bank soundness indicators (in percent) $1 /$} \\
\hline Capital adequacy ratio $2 /$ & 15.3 & 14.7 & 13.4 & 12.5 & 12.7 \\
\hline Unsatisfactory assets/total loans & 12.4 & 11.3 & 14.4 & 14.8 & 12.3 \\
\hline Provision for loan losses/unsatisfactory assets & 22.3 & 23.8 & 19.5 & 23.5 & 22.0 \\
\hline Net profit before taxes/average assets & 1.6 & 1.7 & 1.4 & 1.6 & 2.1 \\
\hline Liquid assets/total assets & 26.7 & 28.7 & 32.3 & 32.4 & 40.6 \\
\hline Gross government exposure/total capital 2/ & 225.3 & 216.6 & 193.0 & 231.2 & 192.4 \\
\hline \multicolumn{6}{|l|}{ External indicators } \\
\hline \multicolumn{6}{|l|}{ Foreign exchange earnings from tourism $3 /$} \\
\hline \multicolumn{6}{|l|}{ Merchandise imports } \\
\hline (12-month percent change in U.S. dollars) & 5.2 & -4.6 & 16.3 & 6.3 & 10.9 \\
\hline Current account balance (percent of GDP) & -8.0 & -10.9 & -13.4 & -9.5 & -14.5 \\
\hline Capital and financial account balance (percent of GDP) & 8.0 & 12.8 & 13.5 & 7.8 & -5.1 \\
\hline \multicolumn{6}{|l|}{ Of which } \\
\hline Inward foreign direct investment & 13.9 & 9.2 & 22.1 & 9.0 & 14.1 \\
\hline \multicolumn{6}{|l|}{ Imputed net international reserves $4 /$} \\
\hline In millions of U.S. dollars & 442 & 502 & 537 & 631 & 597 \\
\hline In percent of broad money & 18.9 & 20.1 & 19.6 & 20.4 & 17.8 \\
\hline Commercial banks' net foreign assets (millions of US\$, end of period) & 38.8 & 34.2 & 133.6 & 150.2 & 370.2 \\
\hline External government debt (millions of US\$, end-period) & 473.0 & 525.8 & 588.2 & 579.1 & 351.0 \\
\hline $\begin{array}{l}\text { External government debt service (in percent of exports } \\
\text { of goods and services) } 5 /\end{array}$ & 8.4 & 8.5 & 8.9 & 9.7 & 30.8 \\
\hline $\begin{array}{l}\text { External interest payments (in percent of exports of } \\
\text { goods and services) } 5 /\end{array}$ & 3.1 & 3.3 & 3.3 & 2.8 & 2.7 \\
\hline $\begin{array}{l}\text { External amortization (in percent of exports of } \\
\text { goods and services) } 5 /\end{array}$ & 5.3 & 5.2 & 5.6 & 7.0 & 28.1 \\
\hline Exchange rate (E.C. dollars per U.S. dollar), end-period & 2.7 & 2.7 & 2.7 & 2.7 & 2.7 \\
\hline Real effective exchange rate appreciation $(+)$ & & & & & \\
\hline (end-period, percentage change) & 3.3 & 1.3 & -2.2 & -2.2 & -0.3 \\
\hline
\end{tabular}

Sources: Eastern Caribbean Central Bank; Ministry of Finance; and Fund staff estimates.

1/ Prudential indicators reported by commercial banks, with infrequent onsite verification by the ECCB.

2/ Domestically licensed banks only.

3/ Based on average daily expenditures by visitors arriving by air and import-weighted export unit values from partner. 4/ ECCU aggregates.

5/ Scheduled. 


\section{SUMMARY OF ANNEXES}

Fund relations. Antigua and Barbuda has never used Fund resources. Its quota is SDR 3.5 million. It is a member of the Eastern Caribbean Currency Union (ECCU), and the EC dollar has been pegged to the U.S. dollar at EC \$2.70 = US\$1 since 1976. Antigua and Barbuda has accepted the obligations under Article VIII, Sections 2, 3, and 4. It maintains an exchange system free from restrictions on the making of payments and transfers for current international transactions.

Relations with the World Bank Group. ${ }^{4}$ The country assistance strategy (CAS) for FY06-09 supports the region's development through: (1) stimulating growth and improving competitiveness; and (2) reducing vulnerability. Like its predecessor, the current CAS does not include any lending to Antigua under the base case scenario. However, Antigua could benefit from participation in the Catastrophe Risk Insurance Facility and the Mainstreaming Adaptation to Climate Change Environmental Protection project.

Relations with the Caribbean Development Bank. ${ }^{5}$ The CDB provides financing of priority projects and technical assistance. Major projects under implementation include: line of credit to the Antigua and Barbuda Development Bank; a basic education project; an airport and seaport security enhancement project; and a poverty assessment project - part of a wider regional programme - to be completed during the final quarter of 2006.

Statistical issues. Antigua has participated in the General Data Dissemination System (GDDS) since October 2000. There are significant problems with real, fiscal, and balance of payments data.

National accounts are plagued by the absence of trade data since 1991. There is no comprehensive labor force survey. Data on central government finances published by the ECCB are broadly in line with the 1986 GFS Manual, but Antigua has not reported data in recent years for the GFS Yearbook and IFS publications. Balance of payments statistics, provided to STA by the ECCB, are reported on an annual basis only and not in the format recommended in the $5^{\text {th }}$ edition of the BOP Manual. The government has indicated that it intends to seek assistance from CARTAC and donors to improve statistics.

\footnotetext{
${ }^{4}$ Adapted from text prepared by Bank staff on October 31, 2006.

${ }^{5}$ Adapted from text prepared by Bank staff on November 1, 2006.
} 
ANNEX I: Fund RELATIONS

As of October 31, 2006

I. Membership Status: Joined February 25, 1982; Article VIII

II. General Resources Account:

Quota

Fund Holdings of Currency

Reserve Position in Fund

III. SDR Department:

Holdings

IV. Outstanding Purchases and Loans:

V. Financial Arrangements:

VI. Projected Obligations to Fund:

VII. Exchange Arrangements:

\begin{tabular}{rr} 
SDR million & Percent of Quota \\
\hline 13.50 & 100.0 \\
13.50 & 99.99 \\
0.01 & 0.05
\end{tabular}

$\underline{\text { SDR million } \quad \text { Percent of Allocation }}$

0.01 n.a.

Antigua and Barbuda is a member of the Eastern Caribbean Central Bank (ECCB), which manages monetary policy and the exchange system for its eight members. The common currency, the Eastern Caribbean dollar, has been pegged to the U.S. dollar at the rate of EC \$2.70 per U.S. dollar since July 1976. In practice, the ECCB has operated like a quasicurrency board, maintaining foreign exchange backing of its currency and demand liabilities of close to 100 percent.

Antigua and Barbuda accepted the obligations of Article VIII, Sections 2, 3, and 4 in November 1983. It maintains an exchange system free from restrictions on the making of payments and transfers for current international transactions.

\section{Article IV Consultation:}

Antigua and Barbuda is on the standard 12-month consultation cycle. The last Article IV consultation was concluded by the Executive Board on December 121 2005. The staff report is IMF Country Report No. 06/145, and the accompanying statistical appendix is IMF Country Report No. 06/146. 


\section{FSAP Participation, ROSCs, and OFC Assessments:}

Antigua and Barbuda participated in the regional ECCU FSAP conducted in September and October 2003. The FSSA is available at www.imf.org/external/pubs/ft/scr/2004/cr04293.pdf. A ROSC for a BCP assessment of Antigua and Barbuda's offshore banking sector is www.imf.org/external/pubs/ft/scr/2004/cr04366.pdf.

\section{Technical Assistance:}

FAD Public expenditure control February 2004

FAD Pension reform May 2005

FAD VAT sensitivity study May-June 2005

LEG Tax legislation on personal income tax January-March 2005

LEG Tax legislation on VAT

LEG Anti money Laundering Issues October 2006

CARTAC has been providing extensive technical assistance to Antigua and Barbuda to assist the authorities in undertaking tax reforms-including the introduction of personal income tax and preparations for the Antigua and Barbuda Sales Tax (a simplified VAT) — as well as public expenditure management, including the introduction of a public sector investment program, and treasury operations management. In addition, CARTAC provides technical assistance through the Structural Adjustment Technical Assistance Program (SATAP). The most recent SATAP mission took place in October 2006. 


\section{ANNEX II: RELATIONS WITH THE WORLD BANK GROUP}

(As of October 25, 2006)

The World Bank's management presented to its board the Eastern Caribbean Sub-Region Country Assistance Strategy (CAS), on September 13, 2005. The World Bank Group's strategy for the four years covered by this CAS (FY06-09) supports the sub-region's development agenda through two main pillars: (1) stimulating growth and improving competitiveness; and (2) reducing vulnerability, by promoting greater social inclusion and strengthening disaster risk management.

The CAS, which covers the period FY 2006-09, does not include any lending to Antigua and Barbuda under the base case scenario. However, during the implementation period, the country could benefit from participation in the Catastrophe Risk Insurance Facility financed through on-lending, possibly through the Caribbean Development Bank. Antigua and Barbuda could also benefit from a GEF-funded Mainstreaming Adaptation to Climate Change Environmental Protection project, which seeks to assist in the incorporation of climate change concerns in sector and regional planning for the OECS nations. Additionally, Antigua and Barbuda will benefit from recently completed, ongoing and planned analytical and advisory activities to support the CAS' two main pillars including the following activities: "Towards a New Agenda for Growth"_-OECS growth and competitiveness study; Caribbean Air Transport Rationalization report (draft recently completed); a Caribbean Skills and Curriculum Study; a report on Institutions, Performance and the Financing of Infrastructure Services in the Caribbean (recently completed); Caribbean Financial Sector and Regulation report; Caribbean Social Projection Strategy Review (draft recently completed); a regional study on Crime and Violence in the Caribbean; and an OECS private sector financing study planned for the current fiscal year. Under the High Case lending scenario, US\$10 million is planned for investment lending and/or Development Policy Lending to support policy reform efforts in the areas of growth and competitiveness (including interventions on Public Sector Modernization and Public Utilities Reform).

The previous CAS, which covered the period FY 2002-06, did not include any lending to Antigua and Barbuda. 


\title{
ANNEX III: RELATIONS WITH THE CARIBBEAN DEVELOPMENT BANK
}

\author{
(As of November 1, 2006)
}

The Caribbean Development Bank (CDB) supports the economic and social development of Antigua and Barbuda through the financing of priority capital projects and technical assistance (TA) and policy dialogue on major developmental issues. CDB's involvement with Antigua and Barbuda has covered such areas as:

- $\quad$ Formulation and implementation of macroeconomic social and sectoral policies geared towards providing a framework for sustainable economic growth;

- Development of infrastructure to facilitate private sector investment;

- Development of human resource to facilitate economic growth and diversification;

- Direct and indirect lending to agriculture, tourism and manufacturing; and

- $\quad$ Emergency disaster rehabilitation.

Major projects under implementation include:

\begin{tabular}{|c|c|c|}
\hline \multicolumn{3}{|c|}{$\begin{array}{l}\text { Antigua and Barbuda: } \\
\text { CDB Assistance by Sector } \\
\text { (cumulative 1970-2005) }\end{array}$} \\
\hline Sector & $\begin{array}{r}\text { In millions of } \\
\text { US dollars }\end{array}$ & $\begin{array}{r}\text { In percent of } \\
\text { total }\end{array}$ \\
\hline Agriculture & 3.5 & 7.1 \\
\hline $\begin{array}{l}\text { Micro and Small } \\
\text { Enterprise }\end{array}$ & 5.7 & 11.6 \\
\hline Manufacturing & 1 & 2 \\
\hline Tourism & 1.9 & 3.9 \\
\hline Power and Energy & 0.3 & 0.6 \\
\hline Transportation & 6.7 & 13.6 \\
\hline Housing & 3.5 & 7.1 \\
\hline Education & 19.6 & 39.8 \\
\hline Multi-sector & 7 & 14.3 \\
\hline Total & 49.2 & 100 \\
\hline
\end{tabular}

- $\quad$ Provision of a consolidated line of credit to the Antigua and Barbuda Development Bank to assist in its lending activities to the housing, education, and micro and small enterprise sectors;

- A basic education project to assist in improving the learning environment at the secondary level, institutional strengthening of the Ministry of Education, and improving the quality of education delivery;

- $\quad$ An airport and seaport security enhancement project to assist in upgrading security at the key air and sea ports to meet revised international standards; and

- $\quad$ Poverty assessment project - part of a wider regional programme - to be completed during the final quarter of 2006.

Over the years, institutional weaknesses have resulted in delays in disbursements on capital and TA projects. As at November 2006, undrawn balances totalled USD7.6 million. 


\section{ANNEX IV: STATISTICAL ISSUES}

Antigua and Barbuda has been a participant in the General Data Dissemination System (GDDS) since October 2000. However, data provision for surveillance purposes is deficient and prevents an accurate assessment of the flows of funds within and among sectors in the economy, which hampers economic analysis. Major improvements are needed to facilitate effective surveillance. There are significant problems with real, fiscal, and balance of payments data.

\section{Real sector}

GDP is compiled at current and constant (1990) prices but follows the 1968 System of National Accounts. National accounts compilation has been plagued by absence of trade data, which has had a serious impact on the estimation of value added in some sectors, especially construction and wholesale and retail trade. However, the Central Statistical Office (CSO) has restarted compilation, with merchandise trade data extracted from data files provided by Customs since the fourth quarter of 2004. The CSO has completed the compilation of historical monthly series from copies of trade documents for the period 1999-third quarter 2002. The Caribbean Regional Technical Assistance Centre (CARTAC) plans to work with the Eastern Caribbean Central Bank (ECCB) in developing a program to improve the compilation of national accounts through the development of a supply and use table as a precursor to rebasing the national accounts.

The consumer price index uses weights from a Household Income and Expenditure Survey conducted during February 1998-January 1999. However, the survey and price collection exclude Barbuda. There is no comprehensive labor force survey and thus little coverage of the labor market developments. An Annual Wages and Hours Worked Survey for the private sector was conducted in 2003, though the coverage of Barbuda was limited. Results of the 2001 population census have been analyzed and published.

\section{Government finance}

Annual and quarterly data on central government finances published by the ECCB are broadly in line with the methodology set up in the 1986 Government Financial Statistics Manual. However, Antigua and Barbuda has not been reporting statistical information in recent years to STA for inclusion in the GFS Yearbook and IFS publications.

\section{Monetary statistics}

Monetary statistics are compiled by the ECCB on a monthly basis with a lag of eight weeks. The data are reported to the Fund regularly. The monetary survey, however, does not include the accounts of credit unions that accept demand and other deposits. The ECCB is taking steps to collect reliable data on credit unions. 


\section{Balance of payments}

Balance of payments statistics are provided to STA by the ECCB. These data are reported on an annual basis only and are not reported in the format recommended in the fifth edition of the IMF's Balance of Payments Manual (1993). Reporting of data on reserves and external debt is in accordance with Antigua and Barbuda's participation in the GDDS. The latest data published in the International Financial Statistics are for 2002.

The GDDS metadata identify priorities for improving BOP data in the short term. These include merchandise trade statistics and visitor expenditure estimates for cruise passengers. Medium term priorities include compiling quarterly balance of payments statistics and partial international investment position tables containing information on debt and monetary operations. 


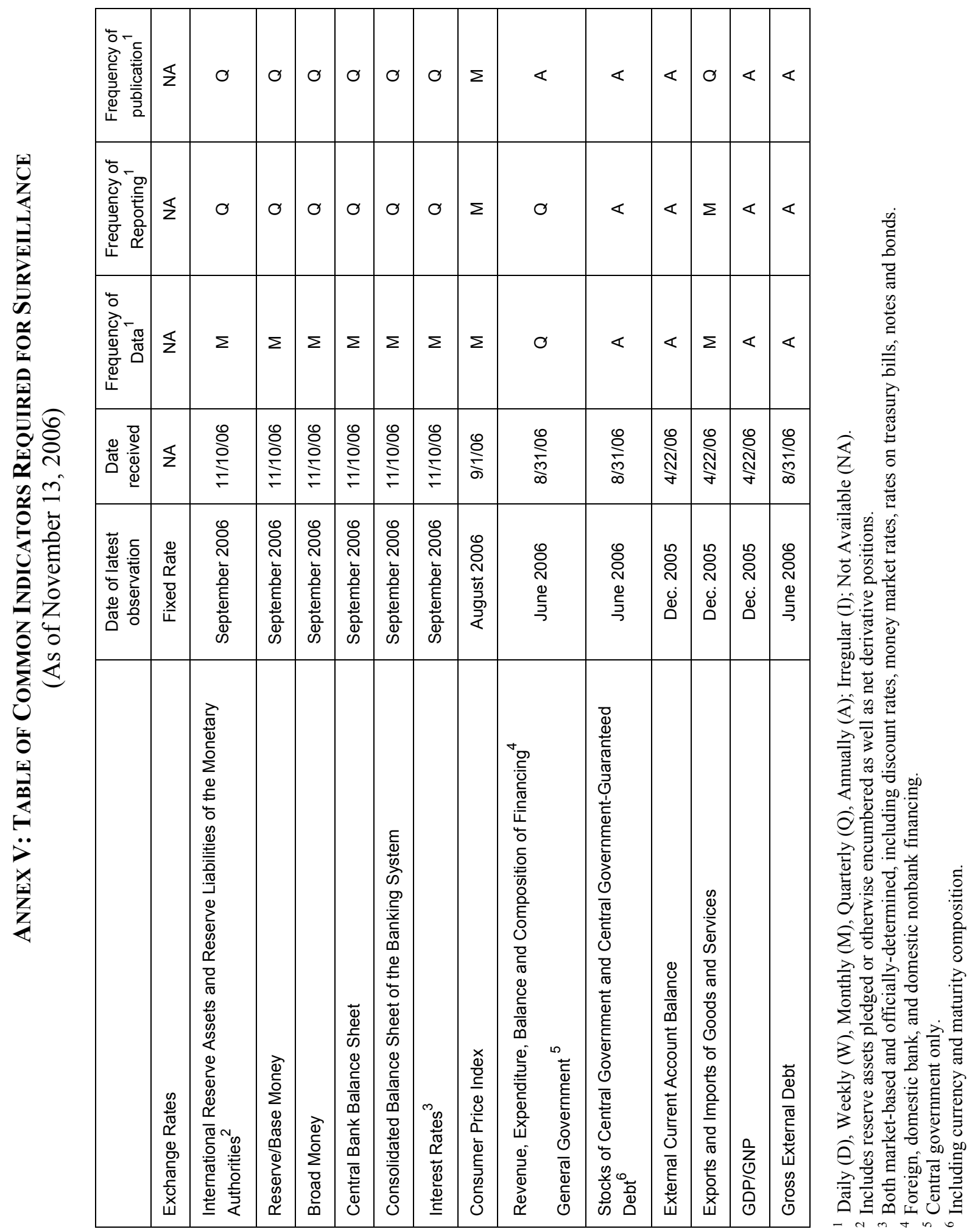




\section{Statement by the IMF Staff Representative January 17, 2007}

1. The information below, largely based on the 2007 Budget Speech, has become available after the issuance of the staff report. These developments do not alter the thrust of the staff appraisal. Rather they reinforce the message of the need for stronger expenditure discipline and management.

2. The 2007 Budget. While the budget reiterated the authorities' commitment to achieving sound public finances and debt sustainability, it also announced a very substantial increase in spending on investment and wages; which, if implemented, would seriously undermine the prospects of achieving viable public finances.

- $\quad$ Wage bill. The 2007 budget shows a nominal wage bill (unadjusted for the savings that would accrue from the separation program) that is over 3 percent of GDP higher than staff's projections. However, even after adjusting for the savings from the separation program, the wage bill would still be over 2 percent of GDP higher.

- $\quad$ Capital spending. Also budgeted is a very large increase in capital spending (to 8 percent of GDP, compared with about $4 \frac{1}{2} 2$ percent projected in the staff report), mainly for infrastructure.

- $\quad$ Fiscal balance. Even if capital spending were contained at the still high 2006 level, and after taking into account wage savings from the voluntary separation program, the budget would imply a primary deficit of more than 4 percent of GDP, compared with a surplus of about 1 percent of GDP recommended in paragraph 10 of the staff report. If implemented, the budget would represent a serious blow to the planned turnaround in Antigua and Barbuda's public finances over the coming years.

3. Authorities' views. In discussion with staff, the authorities acknowledged that the spending ceilings announced in the budget speech were high, but reaffirmed their intention to work toward achieving the fiscal adjustment described in the staff report consistent with achieving debt sustainability.

4. Tax reforms. On a positive note, tax reforms are on track. The modernized property tax has come into effect, and the value-added tax is to be implemented on January 29, 2007, as expected. Preparations are well underway and there has been a sharp increase in registration in recent weeks. The government is receiving technical assistance from CARTAC in the form of four experts (for a 2-3 week period), and has also hired outside experts, to ensure a successful introduction of the VAT. 
5. Gasoline pricing mechanism. The government announced an imminent move to a flexible oil pricing mechanism in 2007 that allows full pass-through of world oil price changes to domestic prices, as done recently by other countries in the region (Grenada since October 2006, and St. Kitts and Nevis since December 2006).

6. Revised banking data. Revised official data on financial soundness for 2001-05, indicate slightly lower capital adequacy and non-performing loan levels than previously reported and slightly higher provisioning (see revised Table 10).

7. Implications. The very large increases in capital spending and the wage bill included in the 2007 budget send a worrying signal about the direction of policies, and, if implemented, would cause a serious setback to restoring sound public finances. Staff has urged the government to prioritize and consolidate expenditures to achieve the fiscal adjustment recommended in the staff report consistent with achieving debt sustainability, and would encourage the authorities to quickly develop a mechanism to restrain expenditure correspondingly.

Antigua and Barbuda: Summary of Central Government Operations, 2006-07 (In millions of Eastern Caribbean dollars)

\begin{tabular}{|c|c|c|c|c|}
\hline & \multirow{2}{*}{$\begin{array}{r}\text { Prel. } \\
\text { Jan.-Sep. } \\
2006\end{array}$} & \multicolumn{2}{|c|}{$\begin{array}{c}\text { Proj. } \\
\text { SM/06/390 } \\
\end{array}$} & \multirow{2}{*}{$\begin{array}{r}\text { Proj. } \\
\text { Budget 1/ } \\
2007\end{array}$} \\
\hline & & 2006 & 2007 & \\
\hline Revenue & 510 & 678 & 649 & 662 \\
\hline Current revenue & 460 & 603 & 637 & 649 \\
\hline Expenditure & 603 & 833 & 757 & 851 \\
\hline Current expenditure & 443 & 665 & 635 & 670 \\
\hline Wages and salaries & 191 & 258 & 242 & 303 \\
\hline Capital expenditure and net lending & 160 & 168 & 123 & 180 \\
\hline Overall balance & -93 & -155 & -108 & -189 \\
\hline Primary balance & -22 & -45 & 24 & -117 \\
\hline (in percent of GDP based on IMF projection) & -0.9 & -1.7 & 0.8 & -4.2 \\
\hline
\end{tabular}

Sources: Antigua and Barbuda authorities; and Fund staff estimates and projections.

$1 /$ Figures as quoted in the Budget speech. Wages are adjusted for arrears and the savings from the separation program, and capital spending is based on the 2005 implementation rate. 
Table 10. Antigua and Barbuda: Selected Indicators of Vulnerability

\begin{tabular}{|c|c|c|c|c|c|}
\hline & 2001 & 2002 & 2003 & 2004 & $\begin{array}{l}\text { Prel. } \\
2005 \\
\end{array}$ \\
\hline \multicolumn{6}{|l|}{ Financial indicators } \\
\hline Broad money (12-month percent change) & 4.8 & 6.3 & 21.1 & 9.2 & 6.9 \\
\hline Private sector credit (12-month percent change) & 3.1 & 8.0 & 2.4 & 1.1 & 10.4 \\
\hline \multicolumn{6}{|l|}{ Commercial bank soundness indicators (in percent) $1 /$} \\
\hline Capital adequacy ratio $2 /$ & 15.3 & 14.7 & 13.0 & 11.6 & 11.6 \\
\hline Unsatisfactory assets/total loans & 12.4 & 11.3 & 10.5 & 12.5 & 10.4 \\
\hline Provision for loan losses/unsatisfactory assets & 22.3 & 23.8 & 26.8 & 27.8 & 26.2 \\
\hline Net profit before taxes/average assets & 1.6 & 1.7 & 1.4 & 1.6 & 2.1 \\
\hline Liquid assets/total assets & 26.7 & 28.7 & 32.3 & 32.4 & 40.6 \\
\hline Gross government exposure/total capital 2/ & 207.4 & 202.2 & 186.6 & 231.1 & 210.2 \\
\hline \multicolumn{6}{|l|}{ External indicators } \\
\hline $\begin{array}{l}\text { Foreign exchange earnings from tourism } 3 \text { / } \\
\text { (12-month percent change) }\end{array}$ & -6.4 & 0.6 & 9.5 & 12.6 & -0.3 \\
\hline \multicolumn{6}{|l|}{ Merchandise imports } \\
\hline (12-month percent change in U.S. dollars) & 5.2 & -4.6 & 16.3 & 6.3 & 10.9 \\
\hline Current account balance (percent of GDP) & -8.0 & -10.9 & -13.4 & -9.5 & -14.5 \\
\hline $\begin{array}{l}\text { Capital and financial account balance (percent of GDP) } \\
\text { Of which }\end{array}$ & 8.0 & 12.8 & 13.5 & 7.8 & -5.1 \\
\hline Inward foreign direct investment & 13.9 & 9.2 & 22.1 & 9.0 & 14.1 \\
\hline \multicolumn{6}{|l|}{ Imputed net international reserves $4 /$} \\
\hline In millions of U.S. dollars & 442 & 502 & 537 & 631 & 597 \\
\hline In percent of broad money & 18.9 & 20.1 & 19.6 & 20.4 & 17.8 \\
\hline Commercial banks' net foreign assets (millions of US\$, end of period) & 38.8 & 34.2 & 133.6 & 150.2 & 370.2 \\
\hline External government debt (millions of US\$, end-period) & 473.0 & 525.8 & 588.2 & 579.1 & 351.0 \\
\hline $\begin{array}{l}\text { External government debt service (in percent of exports } \\
\text { of goods and services) 5/ }\end{array}$ & 8.4 & 8.5 & 8.9 & 9.7 & 30.8 \\
\hline $\begin{array}{l}\text { External interest payments (in percent of exports of } \\
\text { goods and services) } 5 /\end{array}$ & 3.1 & 3.3 & 3.3 & 2.8 & 2.7 \\
\hline $\begin{array}{l}\text { External amortization (in percent of exports of } \\
\text { goods and services) 5/ }\end{array}$ & 5.3 & 5.2 & 5.6 & 7.0 & 28.1 \\
\hline $\begin{array}{l}\text { Exchange rate (E.C. dollars per U.S. dollar), end-period } \\
\text { Real effective exchange rate appreciation }(+)\end{array}$ & 2.7 & 2.7 & 2.7 & 2.7 & 2.7 \\
\hline (end-period, percentage change) & 3.3 & 1.3 & -2.2 & -2.2 & -0.3 \\
\hline
\end{tabular}

Sources: Eastern Caribbean Central Bank; Ministry of Finance; and Fund staff estimates.

1/ Prudential indicators reported by commercial banks, with infrequent onsite verification by the ECCB.

2/ Domestically licensed banks only.

3/ Based on average daily expenditures by visitors arriving by air and import-weighted export unit values from partner.

4/ ECCU aggregates.

5/ Scheduled. 


\section{INTERNATIONAL MONETARY FUND}

EXTERNAL

Public Information Notice

RELATIONS

DEPARTMENT

Public Information Notice (PIN) No. 07/7

International Monetary Fund

FOR IMMEDIATE RELEASE

$70019^{\text {th }}$ Street, NW

January 25, 2007

Washington, D. C. 20431 USA

\section{IMF Executive Board Concludes 2006 Article IV Consultation with Antigua and Barbuda}

On January 17, 2007, the Executive Board of the International Monetary Fund (IMF) concluded the 2006 Article IV consultation with Antigua and Barbuda. ${ }^{1}$

\section{Background}

The government of Antigua and Barbuda has adopted an ambitious reform program in its endeavor to pull the economy from decades of fiscal weakness_characterized by persistent fiscal deficits, a triple-digit debt burden, endemic arrears, and a large civil service-and declining growth rates. The reform agenda includes comprehensive tax reforms, civil service downsizing, measures to improve the investment climate, plans to reform the ailing social security system, and an impending strategy to regularize relations with creditors. These efforts have been complemented by extensive outreach to build public support. Successful implementation of the ongoing and planned reforms could mark a watershed for Antigua and Barbuda's economic prospects.

The reform drive has benefited from an upswing in recent economic activity. The economy is experiencing its third consecutive year of high growth, driven by a construction boom in hotels and housing, as well as projects related to the 2007 Cricket World Cup. Growth in 2006 is

\footnotetext{
${ }^{1}$ Under Article IV of the IMF's Articles of Agreement, the IMF holds bilateral discussions with members, usually every year. A staff team visits the country, collects economic and financial information, and discusses with officials the country's economic developments and policies. On return to headquarters, the staff prepares a report, which forms the basis for discussion by the Executive Board. At the conclusion of the discussion, the Managing Director, as Chairman of the Board, summarizes the views of Executive Directors, and this summary is transmitted to the country's authorities.
} 
expected to reach 8 percent, among the highest in the region. Over the medium term however, growth will slow as the construction boom winds down. Inflation has remained low, largely reflecting the stability provided by the regional quasi-currency board arrangement.

Fiscal outcomes deteriorated in 2005 but are expected to improve in 2006. Data till the first half of 2006 show an improvement in the fiscal position, largely due to revenue gains, while capital expenditure increased sharply in preparation for the Cricket World Cup. The government was able to access the regional government securities market-the first time ever for Antigua and Barbuda-and use proceeds to partly pay off high-end debt. Despite these efforts, arrears continued to accumulate and the debt stock remains in excess of 100 percent of GDP.

The external current account deficit increased to 15 percent of GDP in 2005 and is projected to widen further to 20 percent of GDP in 2006 , but will be fully financed by foreign direct investment.

The financial sector faces risks in the context of a lending boom—by both, the banking and non-banking financial sector-and already high non-performing loan levels at locallyincorporated banks. Some progress has been made in banking sector supervision with the implementation of the revisions to the uniform Banking Act. Legislation for the supervision of the non-bank financial sector (by the Financial Services Regulatory Commission) has been prepared but is yet to be approved by the Parliament. The authorities are continuing to strengthen their Anti Money-Laundering framework.

\section{Executive Board Assessment}

Directors welcomed the government's program to resolve long-standing fiscal and debt problems, raise growth prospects, and build a consensus to support difficult and ambitious reforms. The strong economic outlook provides a good opportunity to advance these reforms.

The tax reform, including the imminent implementation of the value-added tax, is a major achievement. At the same time, it will be important to strengthen tax administration and tax compliance.

Directors emphasized that tight control over expenditure will be crucial to achieve fiscal sustainability. In this light, the sharp increase in wage and investment spending in the 2007 budget, if implemented, would set back plans to restore viable public finances. Directors welcomed the authorities' intention to work toward achieving the fiscal adjustment as originally envisaged.

Directors supported the government's intentions to regularize relations with creditors and achieve debt sustainability. They encouraged the authorities to maintain an open and collaborative approach with all creditors and to make progress in resolving outstanding arrears. 
Structural reforms - in particular, labor market reforms and improvements in infrastructurewill be important to sustain growth and external competitiveness. The efforts to enhance the transparency of the incentive regime through the Investment Authority Act are commendable, but consideration should also be given to a broader reform of the tax incentives system, perhaps at a regional level.

Directors welcomed the government's stated intentions on pension reform, needed to ensure the long-term sustainability of the universal pension scheme and to address budgetary pressures related to population aging. Directors recommended that plans for social security reform also cover civil service pensions, and that consideration be given to integrating the two systems.

Directors urged a further strengthening of financial sector supervision, in particular with respect to the expanding and thus-far unregulated non-bank financial sector.

Directors welcomed the authorities' efforts to reorganize the statistics department, and encouraged them to persevere with improvements in data needed for policy making and surveillance. They supported the provision of technical assistance in these areas as needed, from CARTAC and other sources.

Public Information Notices (PINs) form part of the IMF's efforts to promote transparency of the IMF's views and analysis of economic developments and policies. With the consent of the country (or countries) concerned, PINs are issued after Executive Board discussions of Article IV consultations with member countries, of its surveillance of developments at the regional level, of post-program monitoring, and of ex post assessments of member countries with longer-term program engagements. PINs are also issued after Executive Board discussions of general policy matters, unless otherwise decided by the Executive Board in a particular case. 
Antigua and Barbuda: Selected Economic and Financial Indicators, 2001-06

\begin{tabular}{|c|c|c|c|c|c|c|}
\hline & 2001 & 2002 & 2003 & 2004 & $\begin{array}{r}\text { Est. } \\
2005\end{array}$ & $\begin{array}{l}\text { Proj. } \\
2006\end{array}$ \\
\hline & \multicolumn{6}{|c|}{ (Annual percentage changes, unless otherwise specified) } \\
\hline \multicolumn{7}{|l|}{ National income and prices } \\
\hline GDP at constant factor cost & 1.5 & 2.0 & 4.3 & 5.2 & 5.3 & 8.0 \\
\hline Nominal GDP at market prices & 4.7 & 1.0 & 5.1 & 8.5 & 6.9 & 9.9 \\
\hline Consumer prices (end of period) $1 /$ & $\ldots$ & 2.6 & 1.8 & 2.8 & 2.5 & 1.0 \\
\hline Consumer prices (period average) $1 /$ & $\ldots$ & 2.4 & 2.0 & 2.0 & 2.1 & 2.0 \\
\hline \multicolumn{7}{|l|}{ External sector } \\
\hline Exports, f.o.b. & -12.6 & -24.7 & 32.9 & 27.7 & 25.8 & 9.9 \\
\hline Imports, f.o.b. & 5.2 & -4.6 & 16.3 & 6.3 & 10.9 & 19.7 \\
\hline Travel receipts (gross) & -6.4 & 0.6 & 9.5 & 12.6 & -0.3 & 5.6 \\
\hline Nominal effective exchange rate (period ave., depreciation -) 2/ & 2.5 & -0.3 & -3.2 & -2.7 & -0.3 & 0.8 \\
\hline \multirow[t]{2}{*}{ Real effective exchange rate (period ave., depreciation -) 2/ } & 3.3 & 1.3 & -2.2 & -2.2 & -0.3 & 0.3 \\
\hline & \multicolumn{6}{|c|}{ (Contribution to broad money growth) } \\
\hline \multicolumn{7}{|l|}{ Money and credit } \\
\hline Net foreign assets & 12.6 & 0.6 & 21.9 & 3.3 & 30.0 & 7.0 \\
\hline Net domestic assets & -7.8 & 5.7 & -0.8 & 5.9 & -23.1 & 6.2 \\
\hline Net credit to the public sector & -1.8 & 0.3 & 3.0 & -1.1 & -1.2 & -3.0 \\
\hline Credit to the private sector & 2.9 & 7.5 & 2.2 & 0.9 & 7.7 & 11.0 \\
\hline Broad money & 4.8 & 6.3 & 21.1 & 9.2 & 6.9 & 13.2 \\
\hline Average deposit rate (in percent per annum) $2 /$ & 4.5 & 4.4 & 4.9 & 4.1 & 3.9 & 4.0 \\
\hline \multirow[t]{2}{*}{ Average lending rate (in percent per annum) 2/ } & 11.6 & 11.4 & 12.8 & 12.0 & 11.4 & 11.1 \\
\hline & \multicolumn{6}{|c|}{ (In percent of GDP) } \\
\hline \multicolumn{7}{|l|}{ Central government } \\
\hline Primary balance & -6.8 & -6.9 & -4.2 & -1.2 & -2.3 & -1.7 \\
\hline Overall balance & -12.4 & -12.2 & -9.5 & -6.1 & -7.1 & -6.0 \\
\hline Total revenue and grants & 19.2 & 21.7 & 21.1 & 21.6 & 21.8 & 26.1 \\
\hline Total expenditure and net lending & 31.6 & 33.9 & 30.7 & 27.7 & 28.9 & 32.1 \\
\hline Identified financing & 5.5 & 6.8 & 11.9 & 6.4 & 8.5 & 6.0 \\
\hline External & 3.9 & 3.2 & 7.3 & 0.1 & -20.9 & 1.7 \\
\hline Domestic & 1.5 & 3.5 & 4.5 & 4.5 & 8.0 & 4.2 \\
\hline Debt relief & $\ldots$ & $\ldots$ & $\ldots$ & 1.9 & 21.3 & $\ldots$ \\
\hline Statistical discrepancy & 6.9 & 5.5 & -2.3 & -0.3 & -1.3 & $\ldots$ \\
\hline \multicolumn{7}{|l|}{ External sector } \\
\hline Current account balance & -8.0 & -10.9 & -13.4 & -9.5 & -14.5 & -20.2 \\
\hline Trade balance & -38.4 & -37.5 & -40.8 & -38.8 & -39.3 & -43.5 \\
\hline Service balance & 32.6 & 31.7 & 30.7 & 33.0 & 29.7 & 27.7 \\
\hline \multicolumn{7}{|l|}{ Of which: } \\
\hline Gross tourism receipts & 38.3 & 38.1 & 39.8 & 41.3 & 38.5 & 37.0 \\
\hline Overall balance & -0.9 & -1.6 & -1.6 & -2.1 & -15.8 & -0.1 \\
\hline External government debt (end of year) & 66.6 & 73.2 & 78.0 & 70.8 & 40.1 & 38.2 \\
\hline \multicolumn{7}{|l|}{ Of which: } \\
\hline Arrears & 14.5 & 19.0 & 23.2 & 22.5 & 16.4 & 15.8 \\
\hline \multicolumn{7}{|l|}{ Scheduled external debt service } \\
\hline (In percent of exports of goods and services) & 8.4 & 8.5 & 8.9 & 9.7 & 30.8 & 5.7 \\
\hline \multicolumn{7}{|l|}{$\begin{array}{l}\text { Memorandum items: } \\
\text { Gross international reserves of the ECCB }\end{array}$} \\
\hline (In millions of U.S. dollars) & 446.0 & 504.8 & 539.9 & 632.4 & 600.8 & $\cdots$ \\
\hline (In percent of ECCU broad money) & 19.1 & 20.2 & 19.8 & 20.5 & 17.9 & $\ldots$ \\
\hline Nominal GDP at market prices (in millions of EC\$) & 1,918 & 1,938 & 2,036 & 2,210 & 2,362 & 2,597 \\
\hline Total government debt (in millions of EC\$) & 2,482 & 2,716 & 2,989 & 3,035 & 2,543 & 2,686 \\
\hline (In percent of GDP) & 129 & 140 & 147 & 137 & 108 & 103 \\
\hline
\end{tabular}

Sources: Antigua and Barbuda authorities; Eastern Caribbean Central Bank; and IMF staff estimates and projections.

1/ Based on preliminary estimates of an unpublished, new consumer price index, beginning January 2001, compiled by the Statistics Division, Ministry of Finance.

2/ Figures for 2006 are as of end-June 2006 
Ministry of Finance and the Economy

Government Office Complex

Parliament Drive

St. John's

Antigua

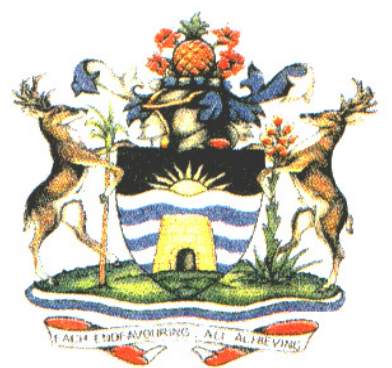

Tel: (268) 462-4860/1/4302

Fax.: (268) 462-1622/5093

Email: finsec@candw.ag

\section{GOVERNMENT OF ANTIGUA AND BARBUDA}

\section{ARTICLE IV MISSION 2006: STATEMENT BY THE GOVERNMENT OF ANTIGUA AND BARBUDA ON THE IMF STAFF REPORT}

Once again, the Government of Antigua and Barbuda was pleased to engage the IMF officials in the annual Article IV Consultation. During this two week consultative process, the IMF team met with representatives from the public and private sectors and civil society in an effort to comprehensively assess macroeconomic developments. We welcomed this opportunity to interact with the IMF on policy issues that are critical to the transformation of our economy and appreciate the continued support and assistance of this institution. At the end of the mission, the Government held a joint press conference with the Fund staff in order to afford the media a chance to freely interact with the IMF team and to receive first hand, the team's perspective on the economy of Antigua and Barbuda.

We concur with the Fund's assessment that there are challenges with which the Government must grapple as it seeks to establish more stable fiscal balances. These challenges are particularly more pronounced as the Government seeks to simultaneously promote economic growth through the empowerment of the private sector. Despite this, however, we remain committed to correcting the fiscal imbalances and achieving debt sustainability. The Government and the Fund staff share, in many instances, similar views and perspectives on how best to meet these challenges. Indeed, both parties agree that the fiscal reform initiatives, particularly tax reform, have been quite ambitious. However, the Government is very pleased with the outcomes of the tax reform efforts, especially given that revenue increased by over 20.0 percent since the commencement of 
the reform process. We also note the Fund's concerns that the efforts on the expenditure side did not move apace with the revenue enhancing initiatives. There have been administrative delays and other constraints and obligations that restricted the speed of implementing expenditure reducing measures in 2006. However, the Government remains dedicated to the task of continuing to improve expenditure management processes and ensuring fiscal prudence.

Though we welcome the positive assessment of the economic outlook for Antigua and Barbuda, the Government is of the view that the projection of 8.0 percent real economic growth for 2006 was conservative and did not fully reflect the impact of ongoing activity in some key sectors, partly associated with Cricket World Cup (CWC) 2007, and the likely impact on other service sectors. Assessments of economic performance done by the Eastern Caribbean Central Bank indicate real economic growth of closer to 12.0 percent in 2006 and a projected rate of between 4.0 and 5.0 percent for 2007.

The Government recognises that there are challenges in respect of the labour market which are compounded by the absence of reliable data on the labour market participation. In this regard, we remain committed to improving the quality and availability of information on the labour force and to implementing appropriate policies to reduce labour market rigidities. It should be noted, however, that the preliminary draft of the Country Poverty Assessment Report indicated that the level of unemployment for the period $2005 / 2006$ is 4.4 percent.

With respect to the fiscal accounts, the Government is pleased that the report highlights the fact that an important fiscal adjustment is taking place. This adjustment has been driven by a very aggressive tax reform effort which has produced significant results. The Government is pleased with the work done on the revenue side of the fiscal reform process which culminated with the introduction of the Antigua Barbuda Sales tax (ABST). We will continue to pursue initiatives to further strengthen tax administration and remain open to receiving the advice and technical assistance from our regional and international counterparts in this regard. Specifically, we will continue to enhance the 
capacity within the Inland Revenue and Customs Departments and will redouble our efforts to complete the implementation of the Customs Renewal Programme - the objective of which is to increase overall efficiency in the Customs Department.

While we have not been as aggressive on the expenditure side of the fiscal reform equation, the Government is no less committed to this crucial element of the process. The Voluntary Separation and Early Retirement Programme (VSEP) is one of the major elements of the Government's programme for expenditure reform. Despite some initial administrative delays, the VSEP is well underway and is expected to generate significant savings on the wage bill. In addition to this programme, the Government is well advanced in the implementation of an expenditure management system which focuses on automating spending procedures, enhancing efficiency and improving accountability and transparency in public expenditure. A key element for the success and sustainability of the expenditure management initiatives will be an effective Treasury Department. In this regard, the Government with the support of the Eastern Caribbean Economic Management Programme (ECEMP) and the Caribbean Regional Technical Assistance Centre (CARTAC), has commenced an initiative to reorganise and strengthen the Treasury Department. Over the next several months, the Government will intensify its efforts on the expenditure side in order to streamline the public sector, rationalise spending, and improve efficiency and productivity. The support of national, regional and international stakeholders will be critical to the success of the programme and the Government will seek their participation at the appropriate level.

We recognise the Staff's concerns with respect to budgeted expenditure for 2007 but reiterate our commitment to ensuring the restoration of sustainable fiscal balances. While the Government notes the points made in the report, particularly in respect of budgeted capital expenditure, we are of the view that expenditure for capital projects, especially with respect to infrastructure, is critical for our overall policy to encourage private sector investment and development. This, in our estimation, is extremely important to our strategy to promote investment and create an environment for private sector led growth. 
However, we agree that prioritization is essential and as such, our intention is to ensure proper expenditure management during the implementation of fiscal policies in 2007.

As stated in the report, the Government still faces some difficulty in attaining debt sustainability. However, reducing the public debt to a more manageable level is a top priority of the Government and we have already commenced the process towards realizing this goal. With the generous financial support of the Canadian International Development Agency (CIDA) we contracted the services of an international debt management firm which assisted us in developing a debt strategy. Over the course of the next few months we expect that, with the continued financial support of CIDA, we will implement this strategy and realize considerable improvement in the debt profile of Antigua and Barbuda.

As the Government continues to pursue measures that will bring about structural change and macroeconomic transformation, we remain focused on creating a private sector friendly and investment enabling environment. In this regard, we are very pleased that with the invaluable assistance of many generous stakeholders, the Antigua and Barbuda Investment Authority (ABIA) is now operational. The Authority, which came into being with the invaluable assistance and generous support of many national, regional and international stakeholders, is responsible for promoting and facilitating investment. It is also responsible for implementing the Government's policy with respect to incentives which is articulated in the legislation. This allows for a more transparent and simplified system for the provision of incentives to all investors.

The availability of reliable and timely data remains a challenge in Antigua and Barbuda and requires deliberate intervention. We expect to implement a programme to strengthen local capacity to enhance the output of the Statistics Division. This programme will focus on increasing human resources, ensuring the availability of appropriate tools and equipment, and providing intensive training. 
Finally, we are once again grateful for the support of the Fund and for the opportunity to engage in open dialogue with the Article IV team. While we appreciate that many of the positions taken by the Fund have merit, all policies and measures adopted by the Government are ultimately based on our broader understanding of and appreciation for the peculiar circumstances on the ground and, more importantly, the overall needs of the people of Antigua and Barbuda. We intend to continue to make full use of the technical expertise of the Fund and will seek the Staff's guidance and advice on issues of importance to the economic transformation and development of Antigua and Barbuda. 